\title{
Theoretical study of dependence of screwing of drilling-pipe connector on thread-process cutting tool profile
}

\begin{abstract}
Screwing is one of the main parameters of the quality of a drill string tapered thread tool joint. It indicates the number of screwing operations that can be applied to this tool joint during drilling. Tool joints that have undergone rejection (determined by a specific criterion - the distance between the end faces of the pin and the box before they are start the screwing) are not permitted to screw. The value of this criterion is proportional to the working height of the threadprofile, which decreases during operation. In this article, it is offered to increase the initial value of the criterion of rejection due to the increase of the work height of the thread profile. This can be done without violating the standard but with the use of a modernized profile of the tool for thread turning. This profile makes it possible to increase the crest diameter of the thread and at the same time ensure sufficient tool life. Due to its usage, the resource of the tool joint can increase by 9-14.5\%, while the cutter's tool life and cost remain unchanged.
\end{abstract}

Key words: drill pipe, tool joint, box, pin, screwing, turning tool, tool life

\section{INTRODUCTION}

The structure of a drill string includes elements that combine drilling pipes with between each other as well as with other objects. These connectors are called as tool joints for drill string elements.

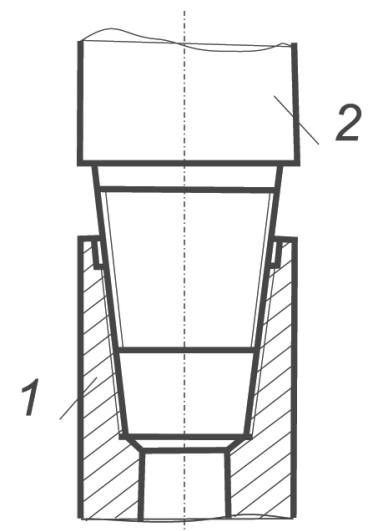

Fig. 1. Scheme of drill string connector: $1-b o x, 2-p i n$
They consist of two parts (Fig. 1): a box (1), which is the female end of the connection, and a pin (2), which is the male end of the connection. One of the quality indicators of a tool joint is its screwing, which is the value that indicates the number of unobstructed screwing and unscrewing processes in it. Such operations always accompany the lowering and lifting process of a drill string. Typically, this value is up to $8-10$ screwing and unscrewing operations for new drill pipes; after this, the tool joints are discarded.

\section{GAP IN THREADED CONNECTION OF DRILL STRING TOOL JOINT}

A tool joint's tapered thread profile according to standards [1] and API 7 (American Petroleum Institute) is schematically presented in Figure 2.

Here are the tool joint tapered thread parameters: $h_{1}$ is the height of the thread profile [mm], $h$ - the 
working height of the thread profile [mm], $P$ - the pitch of the thread [mm], $a$ - the width of the thread crest [mm], and $\alpha / 2$ - half of the thread profile angle.

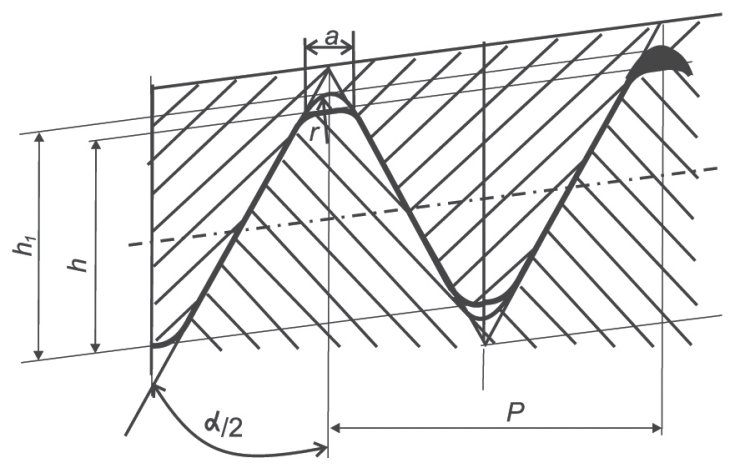

Fig. 2. Scheme of tool joint tapered thread according to API 7 standard

According to this standard, there is always a structural gap between the pin and the box; the width of this is indicated by $a$. In the right part of the diagram, the specified gap is tinted black for clarity. This gap according to the standard has a technological purpose. The values of $h, h_{1}$, and $a$ are optional and are intended for the design of a cutting tool for thread manufacturing. According to the author of [2], the existence of this gap is one of the most important reasons for the loss of tightness in a cut, especially after 3-4 operations of screwing - unscrewing. In the article [3], it is said that the speed of the duct of drilling mud decreases from $30-50 \mathrm{~m} / \mathrm{min}$ to $1 \mathrm{~m} / \mathrm{min}$ when the value of $a$ decreases from the standard value of $1.6 \mathrm{~mm}$ to the of $1-\mathrm{mm}$ value offered by the author. In paper [4], it is offered to reduce the height of the gap from $0.45 \mathrm{~mm}$ to $0.15 \mathrm{~mm}$. However, turning to the full depth of the workpiece will be sharply reduced and the technological stability will decrease accordingly to the cutter.

To ensure long tool life, it is suggested to use a cutter with a non-zero value of the back-rake angle, although no known companies show any thread cutting tool with positive or negative values of this angle at the tool nosein their catalogs [5].

\section{ANALYSIS OF VARIANTS OF INITIAL CONTACT OF THREADS OF SCREW AT MOMENT OF INSTALLATION OF PIN INTO BOX}

The process of inserting the pin into the box precedes the process of their screwing. In publication [6], four variants of the initial contact of the threads of the drill string screw at the pin-installation moment into the box are considered. Figure 3 shows these four options. Option a illustrates Position I. In this position (as in Positions II and III [Options b and c]), the contact between the threads occurs at the crests of the thread screw. In Variant d, Position IV illustrates the contact between the pin and the box by the thread flanks. a)

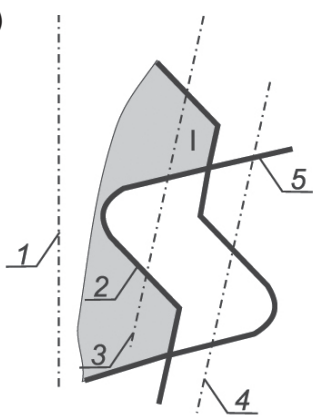

c)

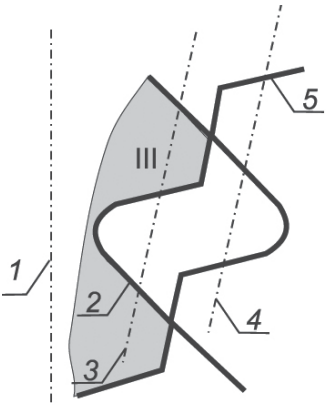

b)

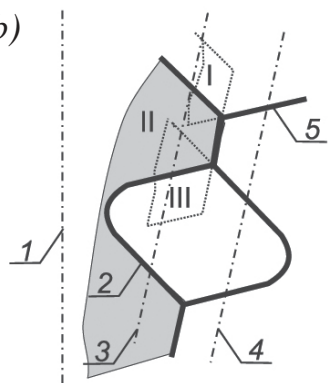

d)

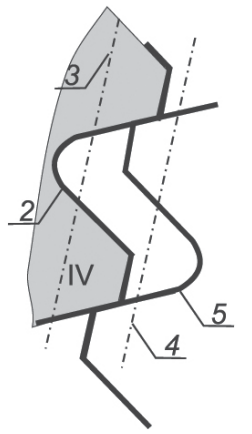

Fig. 3. Schemes of initial contact of threads of tapered screw at moment of pin installation into box: 1 -axis of screw thread, 2 - contour of pin thread, 3 - pitch diameter of pin thread, 4 - pitch diameter of box thread,

\section{5 - contour of box thread}

At the time of the installation of the box under the influence of the weight of all string grid-screwed elements, pressure is created, which depends on the weight of the drill string and the area of contact between the pin and the box. So, the greatest pressure corresponds to the smallest area, which is obviously in Positions I and III (Variants a and c in Fig. 3). As lightly larger area of contact can be seen in Position II (Option b). Option d provides the greatest contact area and, accordingly, the least amount of pressure created by the weight of the drill string. The wearing intensity of the thread-screw surface depends on the pressure; i.e., Option d illustrates the position of IV, which provides the least intense action when the pin insertion into the box is repeatedly applied for their further repeated screwing. 


\section{CRITERION OF TOOL JOINT TAPERED THREAD}

By the criterion of rejection of the tool joint tapered thread most often in the practice of drilling the value $H$ (Fig. 4) is applied. This value defined between the pin end face and box end face at the moment of the pin setting into the box before their screwing start [6]. This method is sufficiently operational, however it does not allow us to control the thread-screw separately for the pin and the box. For the purpose of analyzing the state of the pin thread separately from the box thread, templates are used. The application of the $H$ criterion and the special template for the pin are shown in Figure 5. The pin is displayed with the number " 1 " on it and the template is displayed with the number " 2 ". The value of $H$ decreases due to the thread flank wearing (value of $e$ ) and thread height wearing (value of $b$ ) and, in theory, the value of $H$ can approach zero. This can be achieved by the following formula:

$$
H=\frac{2 h}{K} \quad[\mathrm{~mm}]
$$

where:

$$
\begin{aligned}
& h \text { - working height of thread profile [mm], } \\
& K \text { - thread taper. }
\end{aligned}
$$

The number of revolutions $(m)$ that must be carried out for the complete screwing-in of the elements of the tapered thread tool joint also depends on the work height of profile $h$ and thread taper $K$ [6]. This can be achieved by the following formula:

$$
m=\frac{2 h}{K P} \quad[\mathrm{~mm}]
$$

where $P$ - thread pitch.

Formulas 1 and 2 correspond to the definition of rejection criterion $H$ for the schemes of the initial contact of the pin with Boxes I, II, and III (Fig. 3).

Figure 6 schematically illustrates the box thread contour of the $A B C D E F H$ as well as the contour of the crest of the pin thread in its initial variants of Contacts I, II, and III. Parameter $\mathrm{x}$ indicates the position of the pin thread crest in the process of screwing from the initial contact and until line $L F$ on the pin crest coincides with line $D E$ on the root of the box. The value of $x$ can be determined by the following formula:

$$
x=\frac{K P_{1}}{2} m=P \frac{K}{2}\left(1-\frac{K}{2} \tan \alpha\right) m[\mathrm{~mm}]
$$

where:

$K$ - thread taper,

$P_{1}$ - thread pitch between bigger flanks (corresponds to segment $G K$ on axis),

$M$ - number of revolutions,

$a$ - thread profile angle.

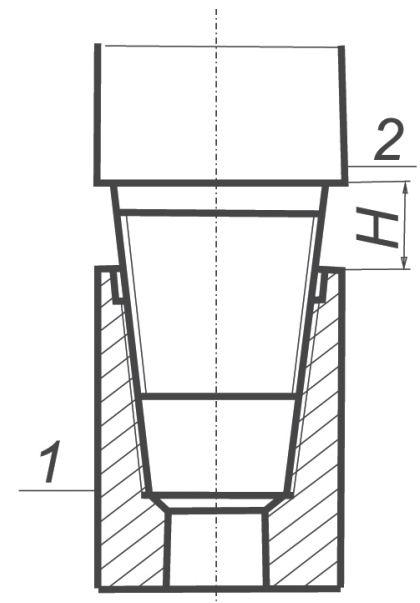

Fig. 4. Scheme for determining $H$ criterion of rejection of tapered thread

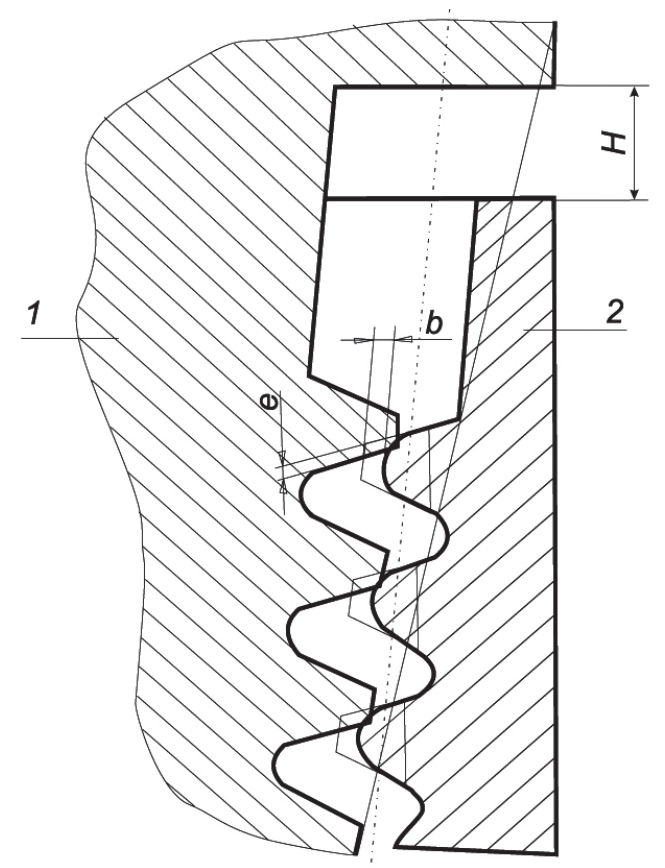

Fig. 5. Scheme for determining rejection criterion $H$ for tapered thread elements and template 


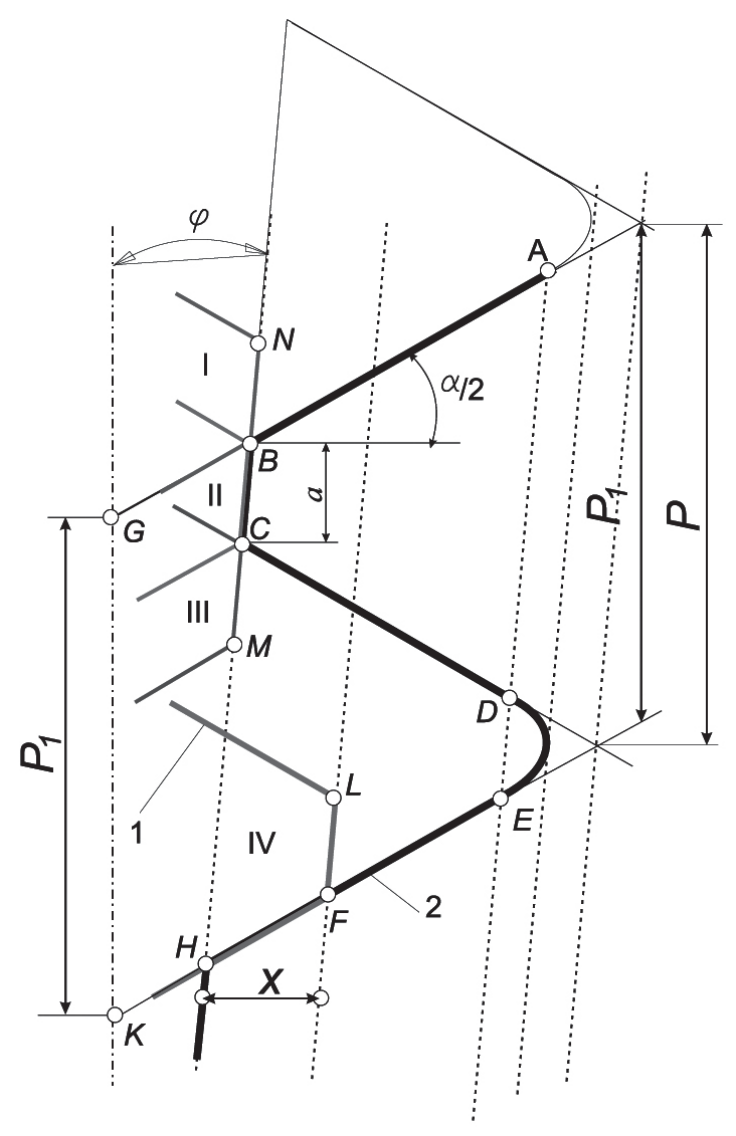

Fig. 6. Scheme of variants of contact of threads at time of installation of pin into box and in process of screwing

In this case, the distance between the end faces of the box and the pin in the process of their interconnection will be changed according to the following formula:

$$
H_{m}=\frac{2(h-x)}{K}[\mathrm{~mm}]
$$

Figure 7 illustrates the position of the pin that comes in contact with the box by the flank surface. The dark gray color corresponds to the position of the pin at the initial moment of contact (as in Position IV in Fig. 3). In order to improve the perception of the initial position in the scheme, the straight-line segment $C L$ that is parallel to the thread-screw axis is applied. This position is characterized by parameter $x_{0}$ - the maximum value of which can be determined by the following formula:

$$
x_{0}=\frac{K}{2}(P-2 a)\left(1-\frac{K}{2} \tan \alpha\right)[\mathrm{mm}]
$$

where $a$ - crest flat width [mm], which in Figure 6 corresponds to length of straight-line segment $B C$.
In accordance to the specified position of the pin, one can find the value of rejection criterion $H_{\text {min }}$, which corresponds to the position of IV by the following formula:

$$
\begin{aligned}
H_{\min } & =\frac{2\left(h-x_{0}\right)}{K}= \\
& =\frac{2 h}{K}-(P-2 a)\left(1-\frac{K}{2} \tan \alpha\right)[\mathrm{mm}]
\end{aligned}
$$

The light gray color illustrates the schematic position of the pin at the time of completing its screw-in into the box. The number of revolutions $\left(m_{\min }\right)$ required to complete the screw-down of the tool joint's tapered thread after the moment of pin insertion into the box or the template corresponding to Position IV are determined by the following formula:

$$
\begin{aligned}
m_{\min } & =\frac{2\left(h-x_{0}\right)}{K P}= \\
& =\frac{2 h}{K P}-\left(1-\frac{2 a}{P}\right)\left(1-\frac{K}{2} \tan \alpha\right)[\mathrm{mm}]
\end{aligned}
$$

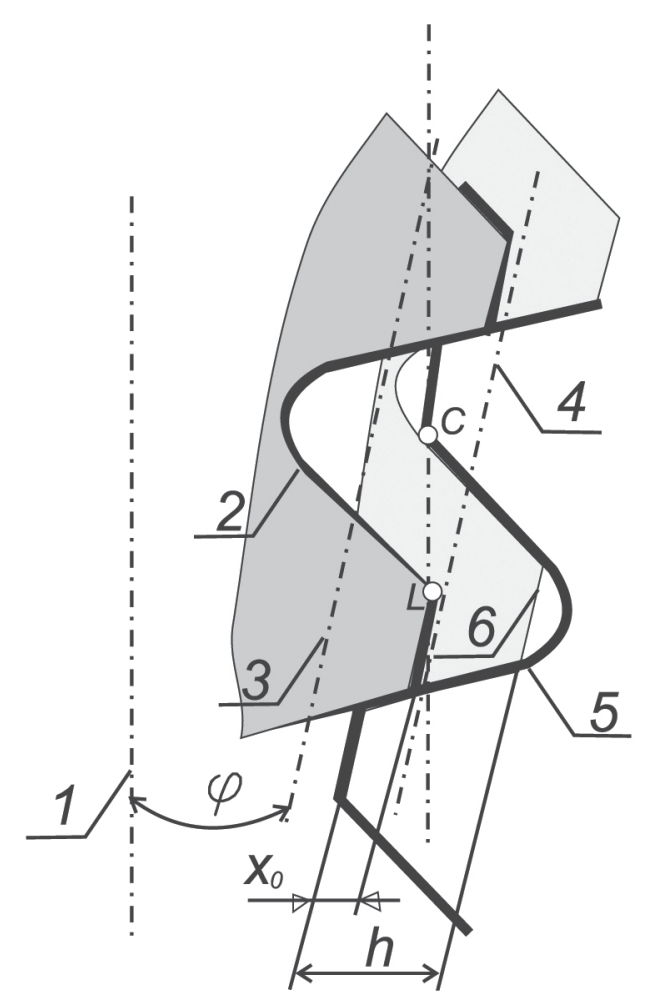

Fig. 7. Initial and final moment of screw-down pin with box: 1 - axis of screw thread, 2 - contour of pin thread at initial moment, 3 - pitch diameter of pin thread, 4 - pitch diameter of box thread, 5 - contour of boxthread, 6 - contour of pin thread at final moment 


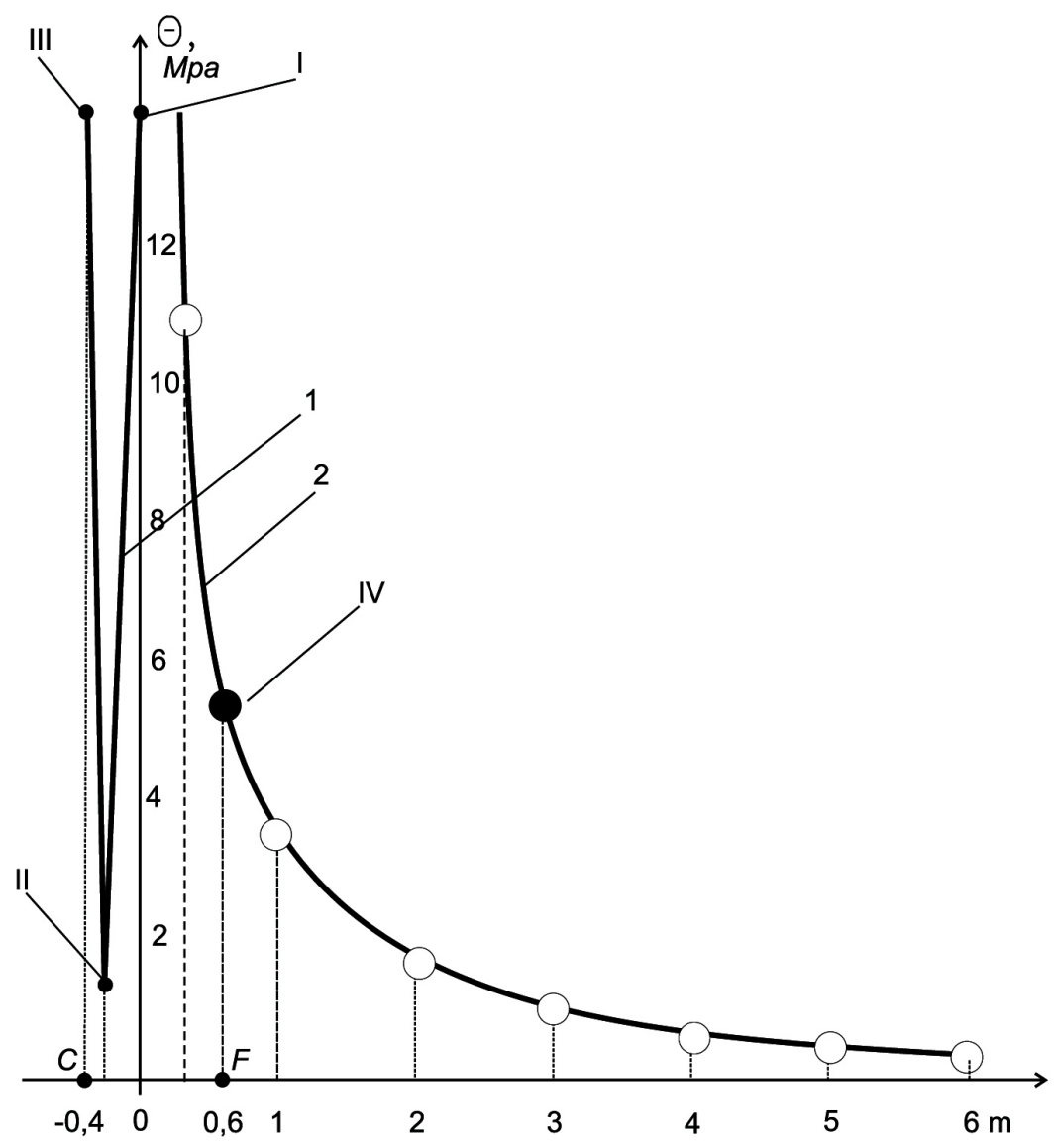

Fig. 8. Pressure changing in tool joint tapered thread 5" FH under action of weight of drill string in process of screwing in different schemes of initial contact of threads: 1 - at initial contact of pin and box only on thread crest

(Provisions I, II, III), 2 - at initial contact of pin and box only on thread flanks

Figure 8 shows the graph of the pressure change on the thread surface under the action of the drill string weight, which depends on the position of the pin at its initial moment of contact with the box before screwdriving and in the process from the beginning to the end of the screwing-in [6]. Points $\mathrm{C}$ and $\mathrm{F}$ limit the stage of setting the pin into the box from the next stage - the actual screw-in. The graph indicates that the initial pin position before the screwing is subjected to pressure values that are greater than (Positions I, II, and III) or similar to the pressure that occurs during the screwing process itself.

The maximum value of the criterion of rejection can actually be determined by the same Formula (1):

$$
H_{\max }=\frac{2 h}{K} \quad[\mathrm{~mm}]
$$

The maximum value of the number of revolutions can actually be determined by the same Formula (2):

$$
m_{\max }=\frac{2 h}{K P} \quad[\mathrm{~mm}]
$$

\section{PROFILE OF CUTTING EDGE OF THREADING TURNING CUTTER WITH NON-ZERO VALUE OF BACK-RAKE STATIC ANGLE AT ITS NOSE}

Article [7] states that the special application for determining the profile half angle of the thread cutter for the manufacture of all standard sizes of the tool joint's tapered threads is createdon the basis of algorithm [8]. The obtained results allow us to design the technological process of the tool joint's tapered thread turning in which the cutter with the calculated cutting-edge profile is executed with a significant static back-rake angle at the its nose and, at the same time, the thread profile formed by it has an initial deviation of within $10-15 \%$ of the permissible deviation of the thread profile half angle. Article [9] proves that the value of the deviation of the thread profile halfangle does not exceed $0.16^{\circ}$ if the value of the static back-rake angle at the nose lies within a range of $-5^{\circ}$ to $5^{\circ}$, while the profile of the cutting edge of the tool 
remains the same as the profile of the thread. According to the authors of [10], the tool life with a value of the static back-rake angle of $-5^{\circ}$ can increase considerably; thus, it can provide increased productivity of the process of turning the closed surfaces of the thread roots.

\section{PURPOSE OF WORK}

The purpose of this work is to upgrade the profile's cutting edge in order to improve the screw-in process of the tool joint's tapered thread and simultaneously increase its tightness while providing the necessary value of the tool life of the cutter.

\section{METHOD TO ACHIEVE PURPOSE}

Graphically and analytically the dependence of the value of the criteria for the rejection of $H_{\min }$ and $H_{\text {max }}$, and the number of revolutions $\left(m_{\min }\right.$ and $\left.m_{\max }\right)$ from the cutter's profile is obtained by changing its optional sizes and applying a non-zero value of the static back-rake angle at the nose.

\section{GRAPHICAL ANALYSIS OF NATURE OF WEAR OF TOOL JOINT'S TAPERED THREAD}

Figure 9 shows a diagram illustrating the nature of the operation of the tool joint tapered thread, which occurs as a result of multiple repetitions of the following processes:

1 - installation of pin into box,

2 - their screw-up,

3 - their further screwing with interference fit.

Process 1 corresponds to the schemes of the initial contact of the pin with the box. In Figure 8, this is a graphical representation, where the argument is the number of revolutions of the screw $(m)$ between points $C$ and $F$. As a result of this process, thread wear occurs primarily on the crest in accordance with the schemes of the initial Contacts I, II, and III (see Figs. $3 a-c)$. Figure 9 illustrates the reduction of the working height of the profile on the thread by $a$ value of $\Delta h$. Graphically, this value seems larger than the thread flank deviation from their standard shapes, which are shown in black.

In Process 1, the installation can also be on the thread flank, which means that the initial contact occurs according to Scheme IV. This corresponds to the part of the graph where the values of the arguments correspond to the points that are located left of Point $F$ but to the right of 0 (see Fig. 8).

Since the pin contact with the box is exactly the larger thread flank, the diagram graphically emphasizes a greater deviation from the face value of the larger thread flank (Area 3) than the smaller one (Section 5).

Process 2 involves the screw-in, during which there is moving contact with the large thread flanks of the pin and the box as well as their operation due to friction under pressure from the weight of the drill string.

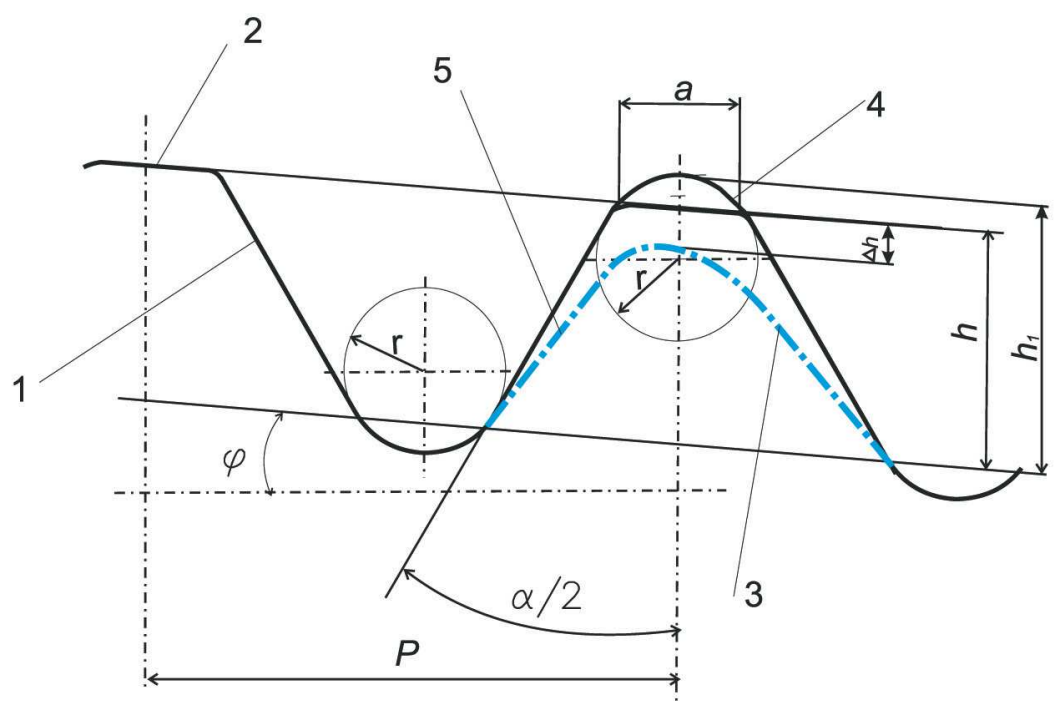

Fig. 9. Diagram graphically illustrating shape of worn thread due to contact pressures and friction of its surfaces as result of installation of pin into box and their screwing: 1 - larger standard flank profile of thread, 2 - crest according to standard, 3 - profile of larger flank profile after prolonged exploitation, 4-standard root of thread, 5 - profile of lower thread flank after prolonged exploitation 
This process corresponds to that part of the graph in Figure 8, where the arguments are represented by the points that are located right of Point $F$. Figure 9 shows that the thread profile long flank deviates more significantly from the initial profile (corresponding to Section 5) than the short one (corresponding to Section 3 ) in this process.

Process 3 - screwing-in with an interference fit occurs when the pin and box are in contact at the short flanks, accompanied by significant deformations in this thread section. It is not the screwing under pressure created by the weight of the drill string but under the tension created by the deformation; therefore, it is not considered within the limits of this article.

Figure 9 illustrates the worn thread crest, but the thread root remains relatively natural (in accordance with the drilling practice and special bench surveys [6]).

\section{RESEARCH OF CUTTING-EDGE PROFILE OF TOOL FOR MANUFACTURE OF TOOL JOINT TAPERED THREAD}

Figure 10 shows a 20 -fold increase in the photo of the cutting edge of the new turning tool for the manufacture of the tool joint tapered thread of the Form IV profile, which is used most in drilling practice.

Figure 11 shows a 20 -fold increase in the photo of the cutting edge of the turning tool for the manufac- ture of the tool joint tapered thread of the Form IV profile after prolonged operation.

Figure 12 shows a diagram that combines the contours of the profile of the new cutter from Figure 10 (solid black line) and of the worn out one from Figure 11 (dotted red line). If you compare these lines, it becomes clear that the cutting edge of the turning tool is the most intensively worn out in the part that forms the thread root.

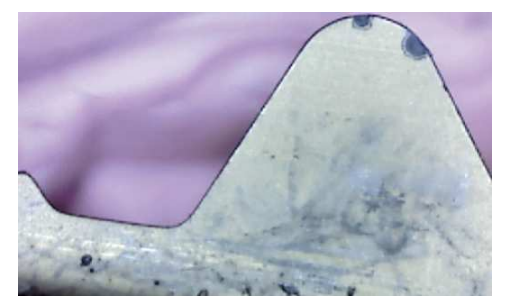

Fig. 10. Photo of cutting part of carbide insert of tool for turning of tool joint tapered thread Form IV (executed at 20-fold increase)

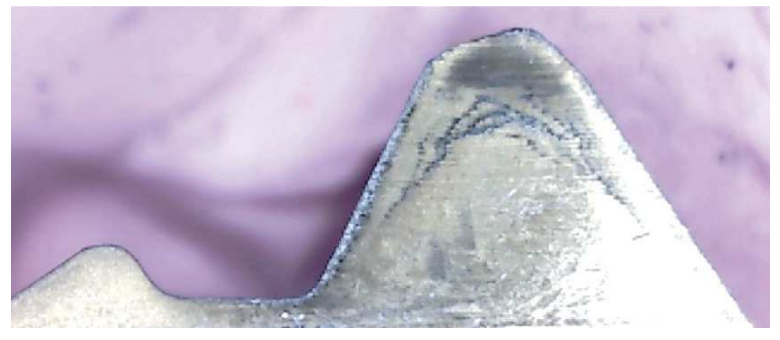

Fig. 11. Photo of cutting part of carbide insert of tool for turning of tool joint tapered thread Form IV after prolonged exploitation (executed at 20-fold increase)

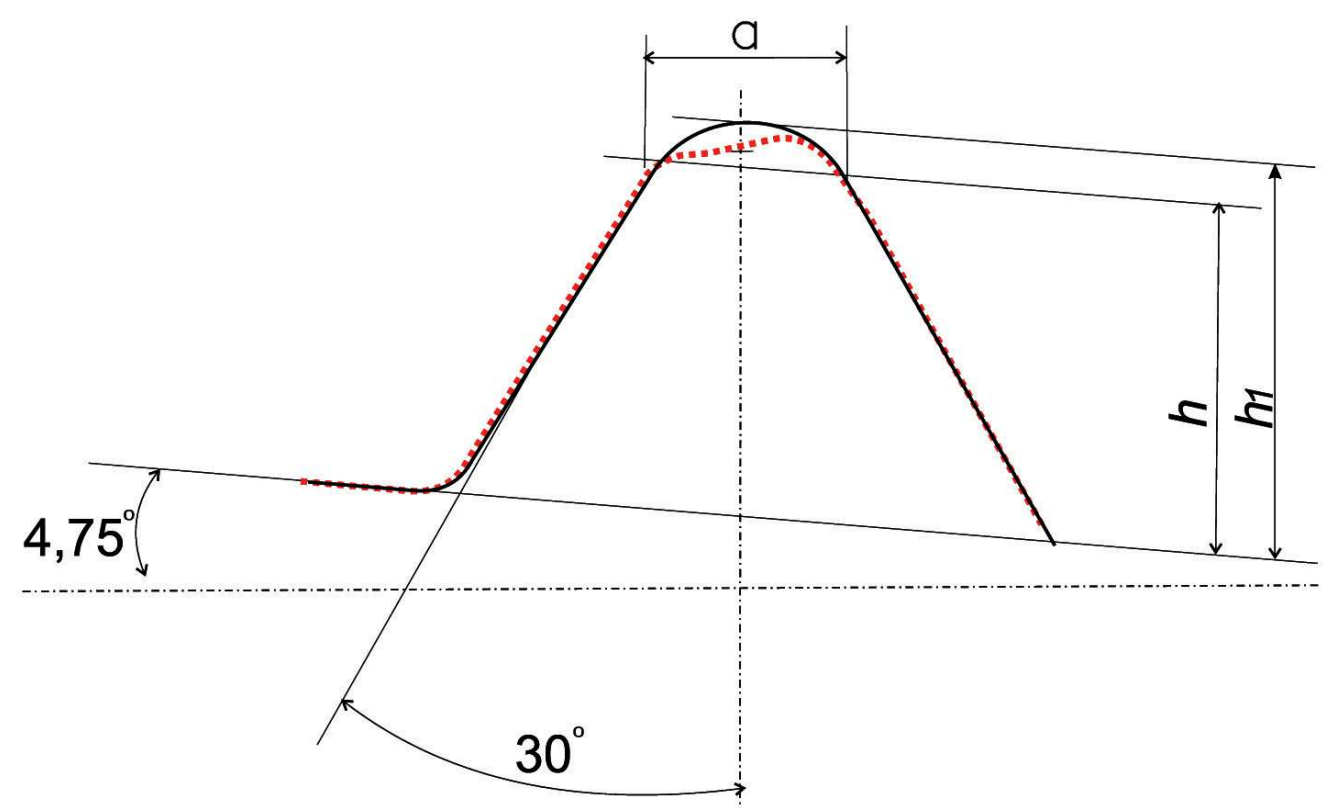

Fig. 12. Scheme of combined contours of new tool cutting edge profile (black line) and cutting edge with worn profile (dotted red line) of turning tools for tool joint tapered thread manufacture 
From Figure 12, it can be concluded that the further operation of the worn cutter does the red line below the top line, which will result in the fact that the pin cannot be screwed into the box due to the interference of their thread surfaces.

\subsection{Ensuring increase in tightness due to reduction of technological GAP}

To reduce the initial value of the height of the gap (which is determined by the previously adopted $h_{1}-h$ formula), it is more expedient to increase the value of $h$ rather than reduce the value of $h_{1}$. This is due to the fact that the part of the cutting edge that wears out most intensively forms the thread root; therefore, it is inappropriate to reduce it.

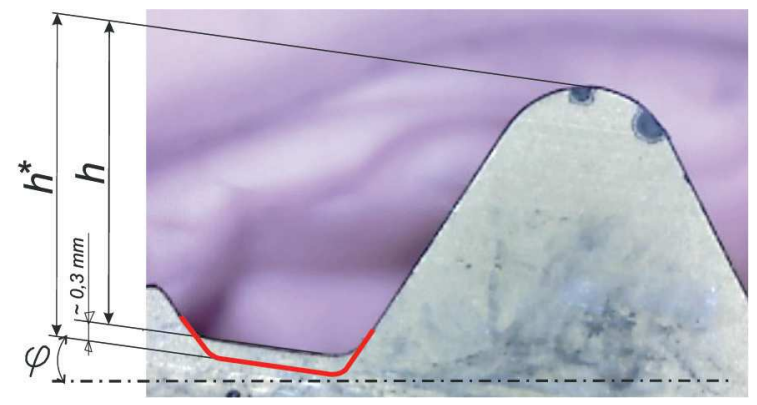

Fig. 13. Similar photo to Figure 10, but only with corrected section of cutting edge that forms crest of tool joint's tapered thread
However, it is quite reasonable to increase the value of $h$ (i.e., it is reasonable to increase the appropriate section of the cutting edge of the tool. Figure 13 shows a cutting-edge photo that is similar to Figure 10, but an additionally modernized profile (red line) is imposed, which confirms that an increase in size $h$ to value $h^{*}$ is due to the transfer of the cutting edge that forms the crest of the thread at $0.3 \mathrm{~mm}$ in accordance with the recommendations [4].

\subsection{Ensuring drill string tooljoint threading tool life}

Figure 14 illustrates the scheme of obtaining the reduced technological gap of $h_{1}-h^{*}$, which can be executed using a turning tool with an adjusted cutting edge (as shown in Fig. 13).

The dotted red line in Figure 14 indicates the view of the worn cutting edge of the cutter at the time of the completion of its working ability.

It is obvious that the value of $h^{*}$ cannot be provided with such an edge, since it has gone beyond the boundary of the figure placed between the dimensions of $h_{1}$ and $h^{*}$. In this case, it is true to ensure the tool's life by adjusting its geometric parameters: in the first place, the back-rake static angle at the nose of the cutter - for example, within a range of $-5^{\circ}$ as recommended $[9,10]$.

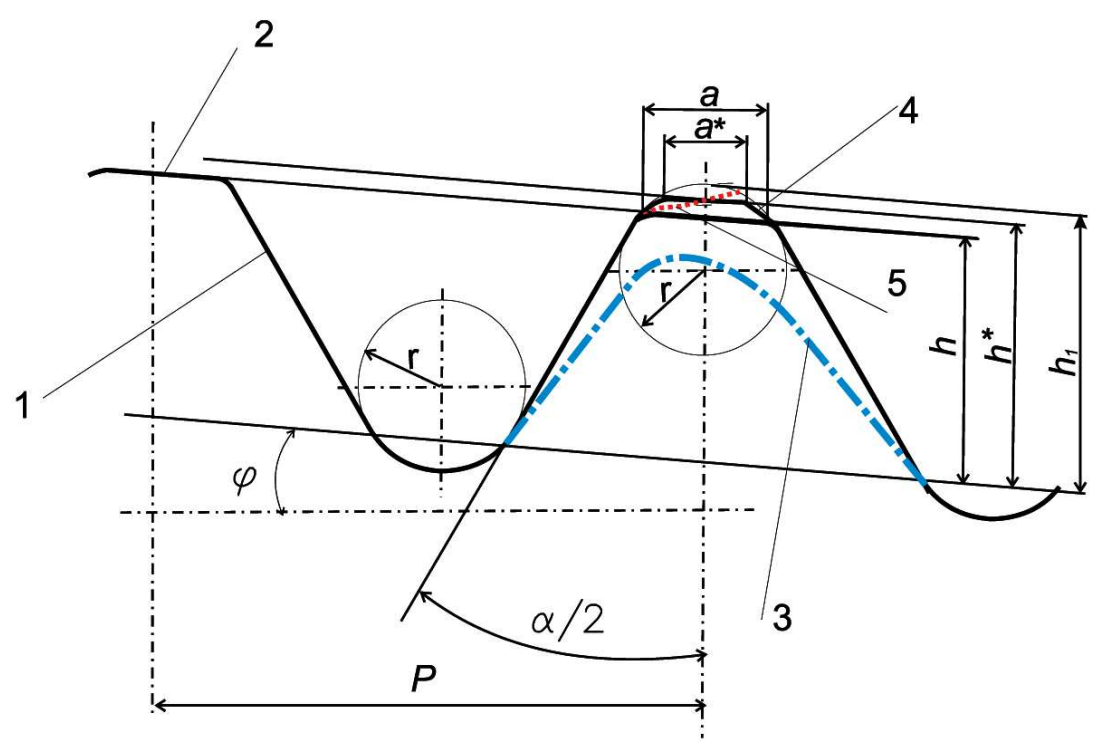

Fig. 14. Diagram illustrates reduction of initial gap as consequence of reducing theoretical limit of cutting edge of tool by increasing value of $h$ to size $h^{*}$. Digits are indicated as follows: 1 - long thread flank of profile according to standard, 2 - thread crest according to standard, 3 - thread profile after prolonged operation, 4 - crest of thread that is executed by using corrected cutting edge, 5 - cutting edge of threading tool after prolonged operation 


\section{INCREASING VALUE OF CRITERION OF REJECTION $\boldsymbol{H}$ AND VALUE OF NUMBER OF REVOLUTIONS $m$}

Figures 13 and 14 show that the value of $h$ can be increased to the size of $h^{*}$; accordingly, the value of $a$ decreases to the size of $a^{*}$. Using Formulas (1)-(4), the value of the criterion of rejection $H$ and the value of number of revolutions $m$ should be calculated for the purpose of obtaining the results, which confirm the idea that the modernized cutter increases the specified parameters according to Figure 13 and recommendations $[9,10]$.

\subsection{Example of calculation of criterion $H$ and value of $m$ for tool joint tapered thread with form of Profile IV}

Input parameters: value of pitch $P=6.35 \mathrm{~mm}$; value of work height $h=2.633 \mathrm{~mm}$; value of taper $K 1: 6$.

According to works $[3,4]$, the decrease in value $a$ from a value of $1.65 \mathrm{~mm}$ to a value of $1 \mathrm{~mm}$ can be achieved by increasing the value of $h$ to $\Delta=0.328 \mathrm{~mm}$. At the same time, the speed of the duct of the drilling mud through the gap will drop 30-50 times according to [3], which means that the abrasive wears lows down sharply. We put these values in Formula 1 and carry out two calculations at $h=2.633 \mathrm{~mm}$ and at $h^{*}$ :

$$
h^{*}=2.633+0.328=2.961 \mathrm{~mm} .
$$

Thus, at a value of $h=2.633 \mathrm{~mm}$, criterion $H=30.98 \mathrm{~mm}$ is obtained, and at a value of $h^{*}=2.961 \mathrm{~mm}$, a value of $H=34.84 \mathrm{~mm}$ is obtained. Thus, Formula 1 actually indicates the functional dependence on the screwing of the drill string tool joint from the profile of the cutting edge. In the numerical dimension on the example of Profile IV, we have the following relative increase in criterion $H_{\%}$ :

$$
H_{\%}=\frac{H^{*}-H}{H}=\frac{34.68-30.98}{30.98} 100=11.94 \%
$$

where $H^{*}$ is the criterion of rejection at $h^{*}=$ $=2.961 \mathrm{~mm}$.
Thus, an increase of working height $h$ by $0.328 \mathrm{~mm}$ leads to an increase in the criterion of the rejection by almost $12 \%$.

We put the values obtained above into Formula (2) and carry out two calculations at the values of $h=2.633 \mathrm{~mm}$ and $h^{*}=2.633+0.328=2.961 \mathrm{~mm}$. Thus, at the values of $h=2.633 \mathrm{~mm}, m=4.88$, and $h^{*}=2.961 \mathrm{~mm}$, the value of $m^{*}=5.49$. Thus, Formula (2) also indicates the functional dependence on the screwdriving of the drill string tool joint from the profile of the cutting edge. In the numerical dimension on the example of Profile IV, we have the following relative increase in criterion $m_{\%}$ :

$$
m_{\%}=\frac{m^{*}-m}{m}=\frac{5.49-4.88}{4.88} 100=12.5 \%
$$

where $m^{*}$ is the value of the number of revolutions at $h^{*}=2.961 \mathrm{~mm}$.

Thus, an increase of $0.328 \mathrm{~mm}$ in the working height of profile $h$ leads to an increase of $12.5 \%$ in the value of the number of revolutions of the tapered tool joint.

\subsection{Comparison of calculated criteria of rejection $\boldsymbol{H}$ and number of revolutions to full screw $\boldsymbol{m}$ of upgraded tapered tool joints and standard ones with IV form of profile}

On the basis of these examples (and after applying Formulas (3) and (5), Table 1 is offered. This includes the calculation of the criteria of rejection for both standard parameters $H_{\max }$ and $H_{\min }$ of Form IV as well as that which is executed by the help of the tool with the modernized profile for the same form.

On the basis of this example, and after application of the Formulas (4) and (6), Table 2 is offered. It includes the calculation of the numbers of revolutions for both standard parameters $m_{\max }$ and $m_{\min }$ of Form IV as well as that which is executed by the help of the tool with the modernized profile for the same form. 
Table 1

Results of calculating criteria of rejection for standard and upgraded execution of tool joint tapered thread (IV form profile)

\begin{tabular}{|c|c|c|c|c|c|c|c|c|}
\hline \multirow{2}{*}{$\begin{array}{l}\text { Name of } \\
\text { parameter }\end{array}$} & \multicolumn{3}{|c|}{ Standard value } & \multicolumn{3}{|c|}{ Upgraded values } & \multicolumn{2}{|c|}{ Relative increase } \\
\hline & $\begin{array}{c}\text { Parameter } \\
\text { value }\end{array}$ & $\begin{array}{l}H_{\min } \\
{[\mathrm{mm}]}\end{array}$ & $\begin{array}{c}H_{\max } \\
{[\mathrm{mm}]}\end{array}$ & $\begin{array}{c}\text { Parameter } \\
\text { value }\end{array}$ & $\begin{array}{l}H^{*}{ }_{\min } \\
{[\mathrm{mm}]}\end{array}$ & $\begin{array}{l}H^{*}{ }_{\max } \\
{[\mathrm{mm}]}\end{array}$ & $\begin{array}{c}\boldsymbol{H}_{\min \%} \\
{[\%]}\end{array}$ & $\begin{array}{c}\boldsymbol{H}_{\max } \% \\
{[\%]}\end{array}$ \\
\hline$P$ & 6.35 & \multirow{5}{*}{28.08} & \multirow{5}{*}{30.98} & 6.35 & \multirow{5}{*}{30.74} & \multirow{5}{*}{34.84} & \multirow{5}{*}{9.4} & \multirow{5}{*}{11.94} \\
\hline$K$ & $1: 6$ & & & $1: 6$ & & & & \\
\hline$a$ & 1.65 & & & 1 & & & & \\
\hline$h$ & 2.63 & & & 2.96 & & & & \\
\hline$a$ & 30 & & & 30 & & & & \\
\hline
\end{tabular}

Table 2

Results of calculating number of revolutions for standard and upgraded execution of tool joint tapered thread (IV form profile)

\begin{tabular}{|c|c|c|c|c|c|c|c|c|}
\hline \multirow{2}{*}{$\begin{array}{c}\text { Name of } \\
\text { parameter }\end{array}$} & \multicolumn{3}{|c|}{ Standard value } & \multicolumn{3}{|c|}{ Upgraded values } & \multicolumn{2}{|c|}{ Relative increase } \\
\hline & $\begin{array}{c}\text { Parameter } \\
\text { value }\end{array}$ & $\begin{array}{l}m_{\min } \\
{[\text { rev] }}\end{array}$ & $\begin{array}{l}m_{\max } \\
{[\text { rev] }}\end{array}$ & $\begin{array}{c}\text { Parameter } \\
\text { value }\end{array}$ & $\begin{array}{l}m_{\min } \\
\text { [rev] }\end{array}$ & $\begin{array}{l}m_{\max } \\
\text { [rev] }\end{array}$ & $\begin{array}{c}m_{\min } \% \\
{[\%]}\end{array}$ & $\begin{array}{c}m_{\max } \% \\
{[\%]}\end{array}$ \\
\hline$P$ & 6.35 & \multirow{5}{*}{4.42} & \multirow{5}{*}{4.88} & 6.35 & \multirow{5}{*}{4.84} & \multirow{5}{*}{5.49} & \multirow{5}{*}{14.5} & \multirow{5}{*}{12.5} \\
\hline$K$ & $1: 6$ & & & $1: 6$ & & & & \\
\hline$a$ & 1.65 & & & 1 & & & & \\
\hline$h$ & 2.63 & & & 2.96 & & & & \\
\hline$a$ & 30 & & & 30 & & & & \\
\hline
\end{tabular}

\section{CONCLUSIONS}

On the basis of the practice of the rejection criteria application and the theoretical research of the cutting-edge profile of the thread tool, the following conclusions have been made:

1. An increase in the work height of thread profile $h$ and $a$ decrease in the crest flat width of a thread profile simultaneously lead to an increase in the tightness of a tool joint tapered thread and the criterion of its rejection $H$ by $9-12 \%$.

2. Increasing the work height of thread profile $h$ and reducing crest flat width $a$ of the thread profile leads to an increase of $12.5-14.5 \%$ in the number of revolutions from the moment of installing the pin into the box until the moment of the full screwing-in.
3. Increasing the work height of thread profile $h$ and reducing the crest flat width of thread profile $a$ do not lead to violations of the standards, as these represent its optional values GOST 28407-90 and API 7.

\section{References}

[1] HOST 28487-90. Mezhgosudarstvennyy standart. Rez'ba konicheskaya zamkovaya dlya elementov buril'nykh kolonn. Profil'. Razmery. Dopuski, "Standartinform" 2010: 75.

[2] Chudyk I.I.: Do vtrat hidravlichno i energii pid chaspromyvanni asverdlovyny, "Rozvidka ta rozrobka naftovykh i hazovykhrodovyshch" 2009, 2: 34-42.

[3] Borushchak L., Onysko O.,Panchuk V.: Research of the impermeability of the tool-joint tape red thread size 2 7/8 reg, Monografia TUR "Problemy Eksploatacji i Zarządzania w Górnictwie”, Kraków 2017: 65-72.

[4] Borushchak L., Borushchak S., Onysko O.: Influence of the technological gap value of the tool-joint tapered thread on the drilling mud flow rate in its screw coupling, "Ukrainian Journal of Mechanical Engineering and Materials Science" 2017, 3, 2: 24-31.

[5] Thread_turning/thread_turning_brochure_english.pdf. www. secotools.com/CorpWeb/Products/Turning/ [dostęp 2017]. 
[6] Semin V.I.: Sovremennyye metody proyektirovaniya rez'bovykh soyedineniy trub neftegazovogo sortamenta dlya stroitel'stva skvazhin: avtoreferat dis. doktora tekhnicheskikh nauk, Moskva 2005.

[7] Onysko O.: Pro funktsional'nu zalezhnist' velychyny polovynnohokuta profilyu zamkovoyi narizi vid velychyn peredn'oho kuta, kuta nakhylu ta polovynnoho kuta profilyurizal'noyi kromky riztsya, in: Optymizatsiya vyrobnychykh protsesiv $i$ tekhnichnyy kontrol' u mashynobuduvanni ta pryladobuduvan$n i$, "Visnyk Natsional'noho universytetu «L'vivs'ka politekhnika»" 2017, 867: 10-28.

[8] Onysko O.: Alhorytm rozrakhunku funktsional'noyi zalezhnosti formy bichnykh profilivhvyntovoyi narizi zamkovoyi konichnoyi dlya elementiv buryl'nykh kolon vid heometrychnykh parametrivriztsya, "Naukoviy visnyk" 2017, 1: 77-81.

[9] Onysko O., Psiuk M.: Analiz zabezpechenniat ochnosti profiliu zamkowo i narizi vyhotovleno iriztsiamyi zza halnym polozhenniam perednoi poverkhni ta zadanoi tochnistiuy ii vstanovlennia, "Visnyk NTU «KhPI». Seriia: Tekhnolohii u mashynobuduvanni" 2017, 17: 10-17.
[10] Onysko O., Panchuk V., Medvid J.: Technology of the oil and gas drill string pipe connector manufacturing with low-permeability level of the drilling mud in it's screw part, $6^{\text {th }}$ International Conference of Applied Science, Banja Luka 2018.

VITALII PANCHUK, D.Sc., Eng. OLEH ONYSKO, Ph.D., Eng. TETIANA LUKAN, M.Sc., Eng. IULIIA MEDVID, M.Sc., Eng. Ivano-Frankivsk National Technical University of Oil and Gas Karpatska 15, Ivano-Frankivsk, Ukraine kmv@nung.edu.ua 


\title{
Teoretyczne badania zależności wkręcania zworników w rurach wiertniczych od profilu krawędzi skrawania noża tokarskiego
}

\begin{abstract}
Kolumna wiertnicza składa się głównie $z$ rur wiertniczych i tączników między nimi. Złacza te są nazywane zwornikami. Skręcanie i odkręcanie to główny parametr wptywajacy na jakość zworników. Ten parametr pokazuje, jaka liczba powtórzeń skręcania-odkręcania połaczenia złaczek wiertniczych jest dopuszczalna $w$ procesie wiercenia otworów naftowych i gazowych. Wykręcanie i odkręcanie zworników określa specjalne kryterium - różnica między końcowa powierzchnia mufy a czopem. Różnica ta zmniejsza się podczas określonej liczby operacji skręcania i odkręcania. To kryterium proporcjonalnie zależy od wysokości roboczej gwintu stożkowego (h), który zmniejsza się podczas wiercenia. Dlatego autorzy proponują zwiększenie początkowej jego wartości. Można to zrealizować bez naruszania standardu, ale $w$ wyniku zastosowania zmodernizowanego profilu narzędzia do gwintowania. Zapewnia to zwiększenie liczby skręcania/odkręcania zworników, zwiększenie szczelności zwornika rur wiertniczych, w którym stabilność technologiczna narzędzia skrawającego jest taka sama. W rezultacie trwałość tej złączki może wzrosnąć o 9-14\%, a jej cena pozostanie bez zmian.
\end{abstract}

Słowa kluczowe: rura wiertnicza, zwornik, mufa, czop, wkręcanie, nóż tokarski, okres trwatości

\section{WPROWADZENIE}

Podstawową częścią przewodu wiertniczego jest kolumna rur płuczkowych. Struktura kolumny rur płuczkowych zawiera elementy, które łączą rury między sobą $\mathrm{i}$ innymi obiektami. Elementy te nazywane są łącznikami przewodu wiertniczego albo wprost zwornikami. Rysunek 1 pokazuje schemat zwornika. Czop (2) jest wystającą częścią gwintowaną na jednym końcu rury, a mufa (1) jest zagłębioną częścią gwintowaną na drugim końcu rury. Każdy zwornik składa się z dwóch części: czopa i mufy. Jednym ze wskaźników jakości zworników przewodu wiertniczego jest wkręcalność, czyli wartość określająca liczbę poprawnych wkręceń i odkręceń.

Takie operacje zawsze towarzyszą procesowi opuszczania i podnoszenia rur wiertniczych. Zazwyczaj w przypadku nowych rur płuczkowych wartość ta wynosi do 8-10 operacji skręcania i odkręcania, po czym rury te są odrzucane.

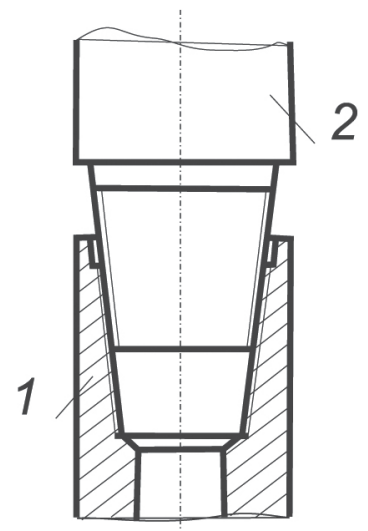

Rys. 1. Schemat zwornika do rur pluczkowych: 1 - mufa, 2-czop 


\section{SZCZELINA W POŁACZENIU GWINTOWYM ZWORNIKA PRZEWODU WIERTNICZEGO}

Profil gwintu połączenia zwornika przewodu wiertniczego zgodnie ze standardem [1] i API-7 (American Petroleum Institute) pokazano na rysunku 2.

Gwint połączenia zwornika przewodu wiertniczego jest określony przez następujące parametry: $h_{1}$-wysokość profilu gwintu [mm]; $h$-wysokość robocza profilu gwintu; $P$ - skok gwintu; $a$ - szerokość wierzchołka gwintu; $\alpha / 2$ - pół kąta profilu gwintu.

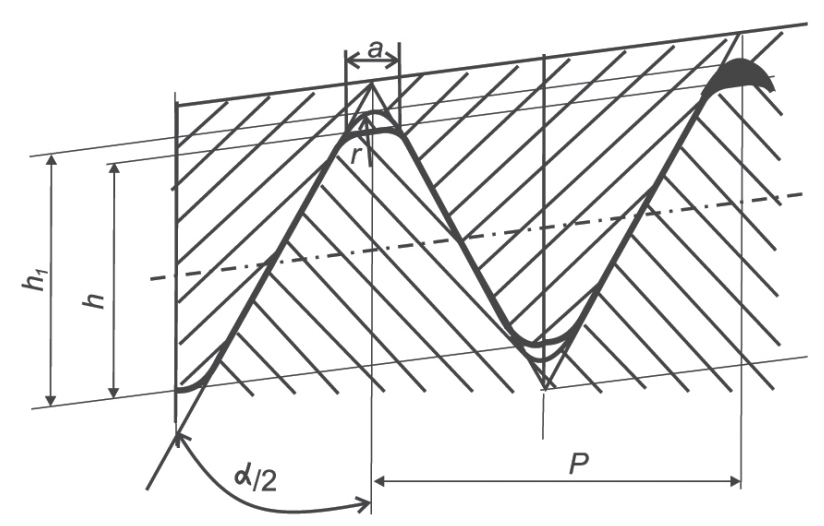

Rys. 2. Schemat gwintu stożkowego zwornika przewodu wiertniczego zgodnie ze standardem API 7

Zgodnie z tym standardem zawsze istnieje luka strukturalna między czopem i mufą, której szerokość jest oznaczona literą $a$. W prawej części wykresu określona szczelina jest pomalowana na czarno. Ta luka zgodnie ze standardem ma cel technologiczny. Wartości $h, h_{1}, a$ są opcjonalne i są przeznaczone do zaprojektowania noża do nacinania gwintów połączenia zwornika. Zdaniem autorów [2] istnienie tej luki jest jedną z najważniejszych przyczyn utraty szczelności zwornika, szczególnie po 3-4 operacjach wkręcania. W artykule [3] mówi się, że gdy wartość $a$ zmniejszy się od standardowej wartości 1,6 $\mathrm{mm}$ do proponowanej przez autorów wartości $1 \mathrm{~mm}$, prędkość wycieku płuczki wiertniczej z odwiertu zmniejsza się z 30-50 m/min do $1 \mathrm{~m} / \mathrm{min}$. W pracy [4] proponuje się zmniejszenie wysokości szczeliny z $0,45 \mathrm{~mm}$ na $0,15 \mathrm{~mm}$. Ale w związku z tym naddatek zostanie znacznie zredukowany i zgodnie z nim zmaleje okres trwałości noża.

Aby zapewnić wysoki okres trwałości noża, zaleca się stosowanie noża z niezerową wartością kąta natarcia, chociaż popularne firmy nie mają w aktualnej ofercie noża do nacinania gwintów z dodatnimi lub ujemnymi wartościami kąta natarcia w punkcie naroża [5].

\section{ANALIZA WARIANTÓW POCZAZTKOWEGO ZETKNIĘCIA ZWOJÓW W MOMENCIE MONTAŻU CZOPA W MUFIE}

Proces wkręcania poprzedza proces ustawiania czopa w mufie. W pracy [6] rozważa się cztery warianty początkowego zetknięcia zwojów gwintu w momencie instalacji czopa w mufie. Rysunek 3 pokazuje te cztery opcje. Opcja a ilustruje pozycję I. W tym położeniu i w położeniach II i III (warianty b i c) kontakt między zwojami znajduje się na wierzchołku zwoju gwintu. W wariancie $\mathrm{d}$ - położenie IV ilustruje kontakt $\mathrm{z}$ bocznymi powierzchniami pomiędzy czopem a mufą. a)

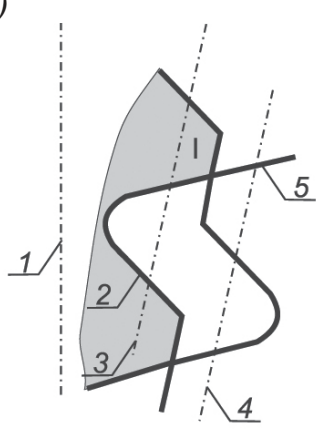

c)

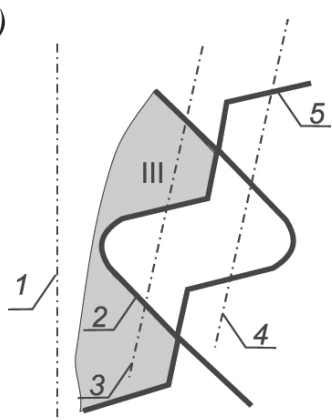

b)

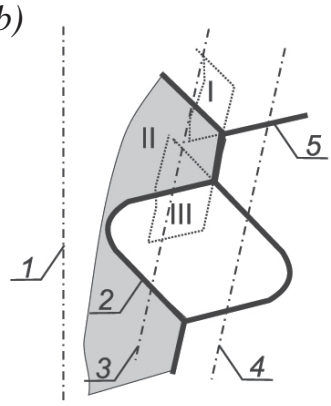

d)

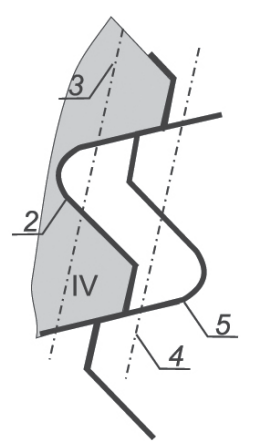

Rys. 3. Schematy początkowego kontaktu zwojów gwintu w momencie montażu czopa w mufie: 1 - oś gwintu, 2 - kontur zwoju gwintu czopa, 3 - średnica podziałowa gwintu czopa, 4 - średnica podziałowa gwintu mufy, 5 - kontur zwoju gwintu mufy

W momencie montażu czopa w mufie pod wpływem ciężaru wszystkich rur kolumny wiertniczej przykręconych jedna z drugą powstaje ciśnienie, które zależy od ciężaru kolumny wiertniczej i obszaru styku między mufą a czopem. Największe ciśnienie odpowiada najmniejszemu obszarowi, który jest oczywiście w pozycjach I i III (warianty a, c na rys. 3). Nieco większa powierzchnia kontaktu znajduje się w pozycji II (opcja b). 
Opcja d zapewni największy obszar styku i odpowiednio najmniejsze ciśnienie wytworzone przez ciężar kolumny wiertniczej. Zużycie powierzchni gwintu zależy od ciśnienia. Opcja d ilustruje pozycję IV, która zapewnia najmniej intensywne zużycie. Przy wielokrotnym montażu czopa w mufie największe zużycie powierzchni jest widoczne na wierzchołkach nawoju gwintu, następnie na bokach, zaś najmniejsze - u podstawy nawoju gwintu.

\section{KRYTERIUM ODRZUCANIA ZWORNIKÓW}

Jako kryterium odrzucania gwintów stożkowych najczęściej stosowany w praktyce wiercenia, jest pomiar odległości $H$ (rys. 4) pomiędzy podpartym końcem czopa 2 a końcem mufy $1 \mathrm{w}$ czasie instalowania jednego $\mathrm{z}$ drugim przed wkręceniem [6]. Zastosowanie kryterium $H$ i specjalnego szablonu przedstawiono na rysunku 5. Numer 1 to mufa, a numer 2 to szablon. Gdy strona boczna gwintu $e$ i wysokość jego profilu $b$ maleją, wartość $H$ również maleje i teoretycznie może zbliżyć się do zera. Można go zdefiniować za pomocą wzoru:

$$
H=\frac{2 h}{K} \quad[\mathrm{~mm}]
$$

gdzie:

$$
\begin{aligned}
& K \text { - wielkość stożka gwintu, } \\
& h \text { - wysokość robocza gwintu stożkowego. }
\end{aligned}
$$

Liczba obrotów $(m)$, która musi zostać wykonana w celu pełnego skręcenia elementów połączenia gwintowego, zależy od wysokości roboczej gwintu stożkowego $(h)$ oraz od wielkości stożka gwintu $(K)$ [6]. Można go zdefiniować za pomocą wzoru:

$$
m=\frac{2 h}{K P} \quad[\mathrm{~mm}]
$$

gdzie $P$ - skok gwintu.

Wzory (1) i (2) odpowiadają definicji kryterium odrzucania zworników $H$ dla schematów pierwszego kontaktu czopa z mufą I, II, III (patrz rys. 3).

Rysunek 6 schematycznie ilustruje kontur gwintu $A B C D E F$ w mufie, a także wierzchołek czopa w jego początkowych wariantach styku z mufą I, II, III. Parametr $x$ reguluje pozycję wierzchołka w procesie wkręcania od początkowego styku i do momentu, gdy jego linia $L F$ pokrywa się z linią $D E$ na podstawie mufy.
Wartość $x$ można określić za pomocą formuly:

$$
x=\frac{K P_{1}}{2} m=P \frac{K}{2}\left(1-\frac{K}{2} \tan \alpha\right) m[\mathrm{~mm}]
$$

gdzie:

$$
\begin{aligned}
K- & \text { wielkość stożka gwintu, } \\
P_{1}- & \text { skok pomiędzy dużymi bokami gwintu } \\
& \text { (odpowiadający segmentowi } G K \text { na osi } \\
& \text { zwornika), } \\
m- & \text { liczba obrotów wkręcania, } \\
\alpha- & \text { kąt zarysu gwintu }\left(60^{\circ}\right) .
\end{aligned}
$$

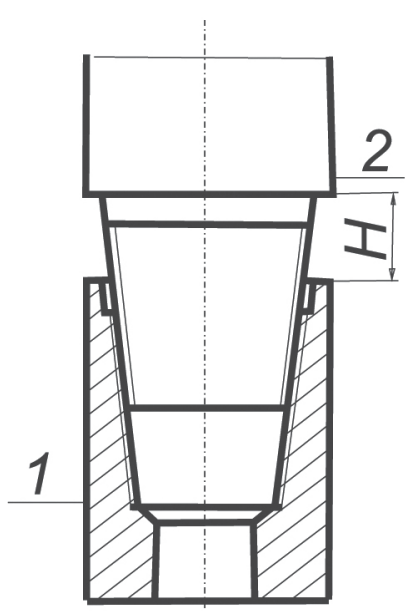

\section{Rys. 4. Schemat wyznaczenia kryterium $H$} dla gwintów stożkowych zwornika

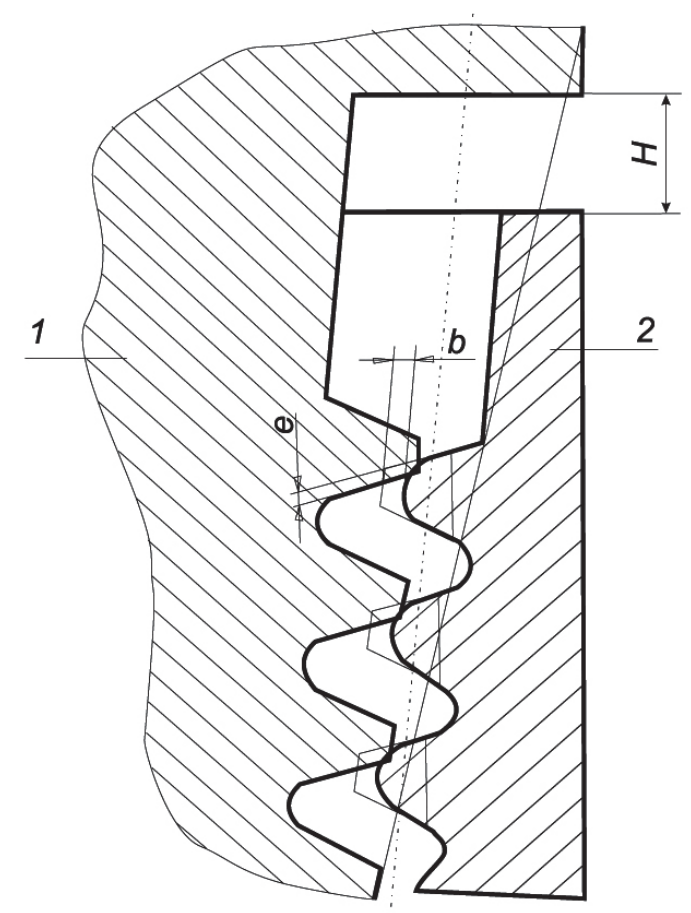

Rys. 5. Schemat wyznaczenia kryterium $H$ dla gwintów stożkowych zgodnie z szablonem 


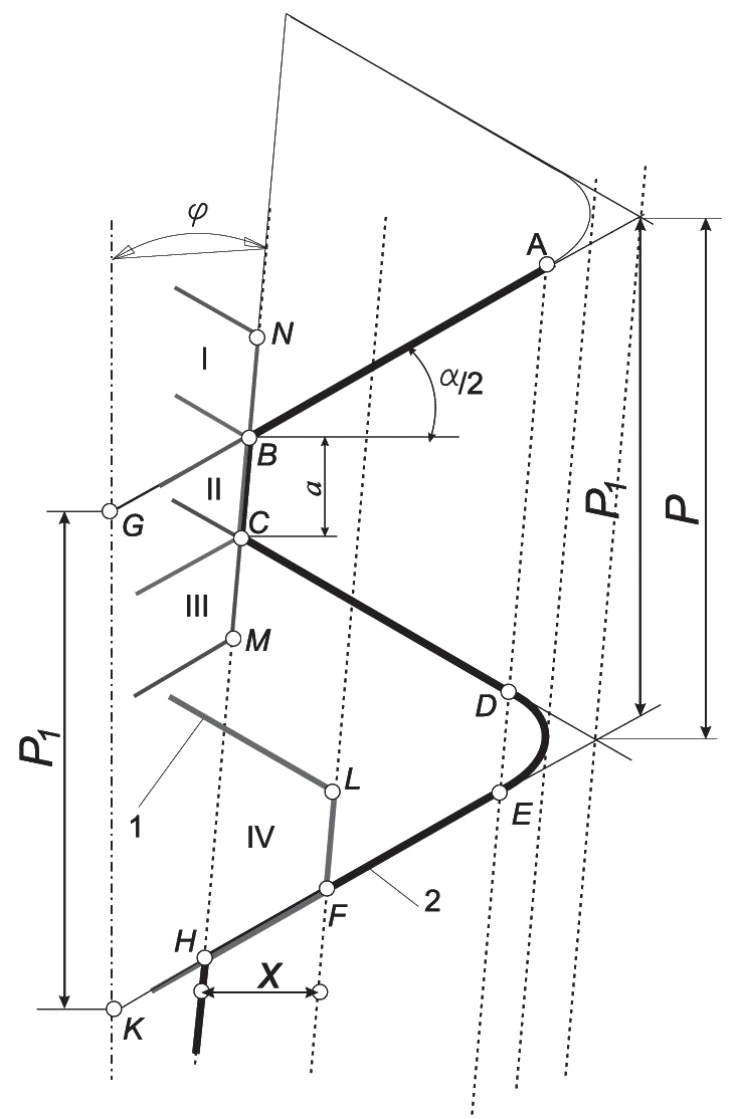

Rys. 6. Schemat wariantów styku zwojów gwintu w momencie montażu czopa w mufie oraz podczas wkręcania

W tym przypadku odległość między końcami czopa i mufy $H_{m}$ w procesie ich wzajemnego połączenia zostanie zmieniona zgodnie z następującym wzorem:

$$
H_{m}=\frac{2(h-x)}{K}[\mathrm{~mm}]
$$

Rysunek 7 ilustruje pozycję czopa, który wchodzi w kontakt z mufą na jej powierzchni bocznej. Ciemnoszary kolor odpowiada pozycji czopa w początkowej chwili kontaktu (jak w pozycji IV na rys. 3). Aby poprawić otrzymanie początkowej pozycji w schemacie, zastosowano sekcję $C L$ równoległą do osi gwintu. Pozycja ta charakteryzuje się parametrem $x_{0}$, którego maksymalną wartość można określić za pomocą następującego wzoru:

$$
x_{0}=\frac{K}{2}(P-2 a)\left(1-\frac{K}{2} \tan \alpha\right) m[\mathrm{~mm}]
$$

gdzie $a$ - szerokość płaskiej części wierzchołka gwintu, która na rysunku 6 odpowiada długości sekcji $B C$.
Zgodnie z określoną pozycją czopa można znaleźć wartość kryterium odrzucenia $H_{\min }$, które odpowiada pozycji IV według wzoru:

$$
\begin{aligned}
H_{\min } & =\frac{2\left(h-x_{0}\right)}{K}= \\
& =\frac{2 h}{K}-(P-2 a)\left(1-\frac{K}{2} \tan \alpha\right)[\mathrm{mm}]
\end{aligned}
$$

Ciemnoszary kolor ilustruje schematyczne położenie czopa w momencie zakończenia jego dokręcania $z$ mufą. Liczbę obrotów $m_{\min }$ potrzebnych do ukończenia wkręcania czopa po zamontowaniu czopa w mufie lub szablonie, co odpowiada pozycji IV, można określić za pomocą wzoru:

$$
\begin{aligned}
m_{\min } & =\frac{2\left(h-x_{0}\right)}{K P}= \\
& =\frac{2 h}{K P}-\left(1-\frac{2 a}{P}\right)\left(1-\frac{K}{2} \tan \alpha\right)[\mathrm{mm}]
\end{aligned}
$$

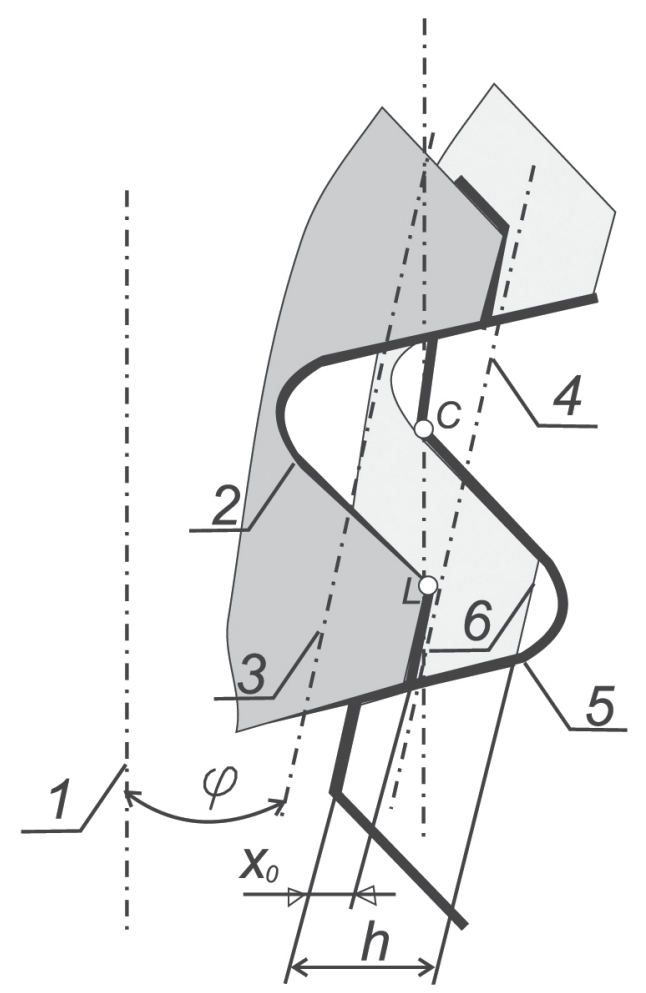

Rys. 7. Poczatkowy i końcowy moment dokręcenia czopa z mufa: 1 - oś gwintu, 2 - kontur zwoju gwintu czopa, 3 - średnica podziałowa gwintu czopa, 4 - średnica podziałowa gwintu mufy, 5 - kontur zwoju gwintu mufy, 6 - kontur zwoju gwintu czopa w końcowy moment dokręcenia czopa z mufa 


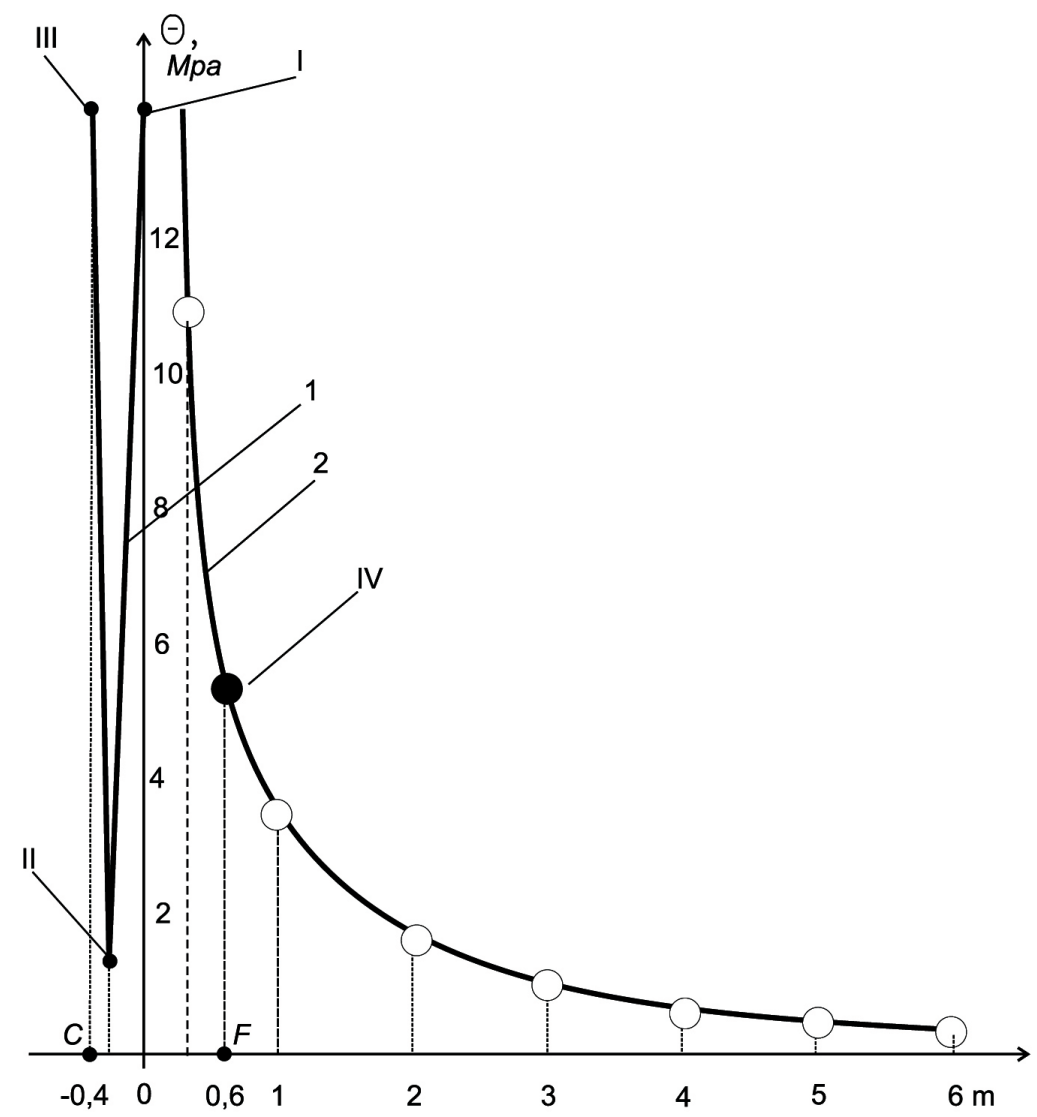

Rys. 8. Zmiana ciśnienia na powierzchni gwintu zwornika 5 1/2 FH pod wplywem ciężaru kolumny wiertniczej w procesie wkręcania różnych schematów pierwszego kontaktu zwojów: 1 - przy pierwszym kontakcie czopa i mufy tylko na wierzchotkach (przepisy I, II, III), 2 - przy pierwszym kontakcie czopa i mufy na powierzchni bocznej gwintu

Rysunek 8 pokazuje wykres zmiany ciśnienia na powierzchni gwintu pod wpływem ciężaru kolumny, który jest zależny od położenia czopa w jego początkowym momencie kontaktu z mufą przed wkręceniem i w procesie od początku do końca wkręcania [6]. Punkty $C$ i $F$ ograniczają etap ustawiania czopa w mufie do następnego - kroku - rzeczywistego wkręcania. Wykres pokazuje, że początkowe połż̇enie czopa przed wkręceniem jest poddawane wartościom ciśnienia, które są większe (pozycje I, II, III) lub są współmierne do ciśnienia występującego podczas samego procesu wkręcania.

Maksymalna wartość kryterium odrzucenia właściwie może być określona za pomocą tej samej formuły (1):

$$
H_{\max }=\frac{2 h}{K} \quad[\mathrm{~mm}]
$$

Maksymalna wartość liczby obrotów również może być określona za pomocą tej samej formuły (2):

$$
m_{\max }=\frac{2 h}{K P} \quad[\mathrm{~mm}]
$$

\section{PROFIL KRAWĘDZI SKRAWAJACCEJ NOŻA TOKARSKIEGO Z NIEZEROWA WARTOŚCIA KĄTA NATARCIA DO NACINANIA GWINTÓW ZWORNIKÓW}

W artykule [7] mówi się, że na podstawie algoryt$\mathrm{mu}$ [8] stworzono specjalne zastosowanie do określania półkątów profilu krawędzi skrawającej noża tokarskiego z niezerową wartością kąta natarcia do nacinania gwintów zworników wszystkich standardowych rozmiarów. Otrzymane wyniki pozwalają zaprojektować proces technologiczny nacinania gwintów, w którym nóż tokarski z obliczonym profilem krawędzi skrawającej jest wykonywany ze znacznym statycznym kątem natarcia w wierzchołku ostrza, a jednocześnie początkowe odchyłki profilu gwintu znajdą się w granicach tylko do $10-15 \%$ od całej tolerancji na wartość półkąta profilu gwintu. Artykuł [9] udowadnia, że odchyłka półkąta profilu gwintu zwornika nie przekracza $0,16^{\circ}$, jeżeli wartość statycznego kąta natarcia w punkcie wierzchołkowym noża leży w zakresie od $-5^{\circ}$ do $5^{\circ}$, podczas gdy profil narzędzia pozostaje taki sam jak profil powierzchni gwintu. Według autorów [10], okres trwałości 
noża o wartości kąta natarcia $-5^{\circ}$ może znacznie wzrosnąć, a tym samym zapewnić zwiększoną produktywność procesu nacinania zamkniętych powierzchni podstaw gwintu. Wzory wskazują, że głównym zasobem zwiększającym wartości kryteriów $H_{\min } \mathrm{i} H_{\max }$ są wartości $h$ i $a$, które mogą powstawać z powodu zmian w profilu krawędzi skrawającej noża.

\section{CEL PRACY}

Celem pracy była aktualizacja profilu krawędzi skrawania ostrza noża, aby zwiększyć wkręcalność stożkowego gwintu łącznika przewodu wiertniczego i jednocześnie zwiększyć jego szczelność, zapewniając wymagany okres trwałości noża do nacinania tego gwintu.

\section{SPOSÓB NA OSIAGNIECCIE CELU}

Graficzna i analityczna zależność wartości kryteriów odrzucania $H_{\min }$ i $H_{\max }$ oraz liczby obrotów do ukończenia wkręcania $m_{\min } \mathrm{i} m_{\max }$ od parametrów profilu krawędzi skrawającej noża została otrzymana dzięki zmianie jego optymalnych rozmiarów $h$ i $a$ oraz z zastosowaniem niezerowej wartości jego statycznego kąta natarcia. Pozwoliło to zapewnić niezbędną trwałość noża tokarskiego.

\section{ANALIZA GRAFICZNA CHARAKTERU ZUŻYCIA GWINTU POŁACZENIAZWORNIKA}

Rysunek 9 przedstawia diagram ilustrujący naturalne zużycie gwintu połączenia w zworniku.
Występuje ono w wyniku wielokrotnego powtarzania procesów:

1 - instalacji czopa w mufie,

2 - ich skręcania (pasowanie luźne),

3 - ich dalszego dokręcania w celu połączenia typu dociskowego (pasowanie ciasne).

Proces 1 (instalacji czopa w mufie) odpowiada schematom pierwszego kontaktu czopa z mufą. Na rysun$\mathrm{ku} 8$ jest to przedstawione graficzne, argumentem jest liczba obrotów wkręcania $m$ między punktami $C$ i $F$. W wyniku tego procesu zużycie następuje głównie na wierzchołku gwintu zgodnie ze schematami początkowego kontaktu I, II, III (patrz rys. 3a-c). Rysunek 9 ilustruje zmniejszenie wysokości roboczej profilu gwintu zwornika o wartość $\Delta h$. Ta wartość jest graficznie większa niż boczne odchylenia powierzchni gwintu od ich standardowego kształtu, które są oznaczone linią czarną.

W procesie 1 instalacja może również odbywać się na powierzchni bocznej, co oznacza, że początkowy kontakt następuje zgodnie ze schematem IV. Odpowiada to części wykresu, w której wartości argumentów odpowiadają punktom znajdującym się po lewej stronie punktu $F$, ale po prawej stronie punktu 0 (patrz rys. 8).

Ponieważ kontakt czopa z mufą odbywa się dokładnie po większym boku gwintu połączenia, diagram graficznie podkreśla większe odchylenie od wartości nominalnej większej strony (linia 3) niż mniejszej (linia 5).

Proces 2 - wkręcanie, podczas którego realizowany jest ruchomy kontakt z dużymi bokami powierzchni gwintowej czopa i mufy oraz ich zużycie z powodu tarcia pod naciskiem ciężaru kolumny. Proces odpowiada części wykresu na rysunku 8 , reprezentowanej przez punkty, które znajdują się po prawej stronie punktu $F$.

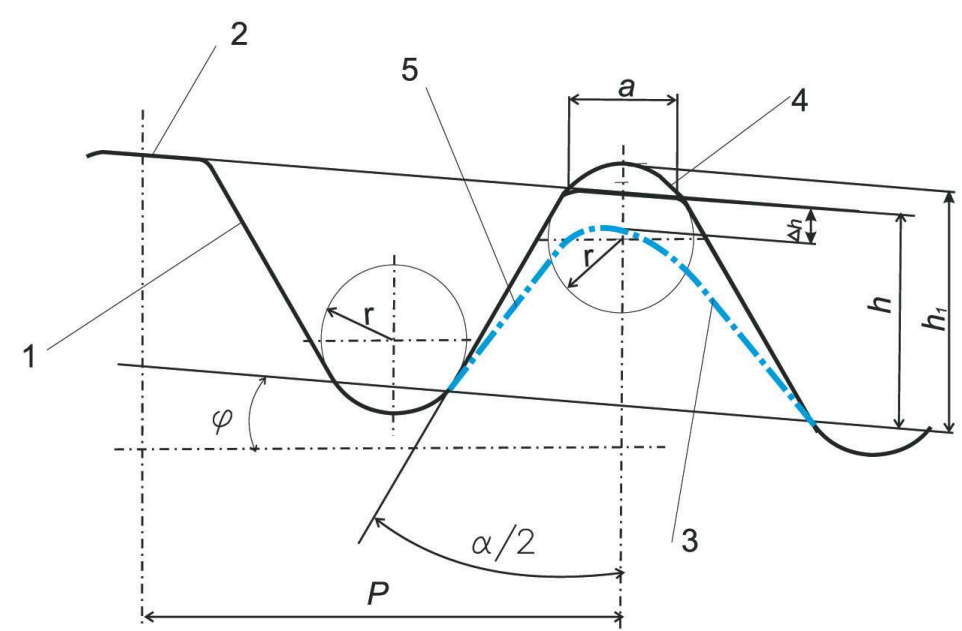

Rys. 9. Schemat ilustrujacy graficznie kształt zużytej powierzchni gwintu zwornika w wyniku nacisków stykowych i tarcia jego powierzchni podczas montażu czopa w mufie i ich skręcania: 1 - większa strona profilu w standardzie, 2 - wierzchołek gwintu zgodny ze standardem, 3 - profil większego boku zwoju po dhuższej eksploatacji, 4 - standardowa podstawa powierzchni gwintu, 5 - profil mniejszego boku zwoju po dłuższej eksploatacji 
Rysunek 9 tego procesu odpowiada linii, która w największym stopniu odbiega od wartości nominalnej większego boku profilu (linia 3) niż strona mniejsza (linia 5).

Proces 3 - dokręcanie w celu połączenia typu dociskowego (pasowanie ciasne) występuje, gdy czop i mufa stykają się małymi bokami powierzchni gwintu, co powoduje ich znaczne deformacje. W ramach tego artykułu nie jest brany pod uwagę.

Rysunek 9 ilustruje zużycie wierzchołka i boków powierzchni gwintowej, a podstawa, zgodnie z praktyką wiercenia i specjalnych badań rur wiertniczych [6], pozostaje stosunkowo nowa.

\section{BADANIA PROFILU KRAWĘDZI \\ SKRAWANIA NOŻA DO PRODUKCJI POWIERZCHNI GWINTOWYCH POŁĄCZENIA RUR WIERTNICZYCH}

Rysunek 10 pokazuje w dwudziestokrotnym powiększeniu zdjęcie krawędzi skrawającej nowego noża do toczenia gwintów zworników rur wiertniczych kształtu IV, która jest najczęściej stosowana w praktyce wiercenia. Jest to nóż o pełnym profilu krawędzi skrawania.

Rysunek 11 pokazuje w dwudziestokrotnym powiększeniu zdjęcie krawędzi skrawającej noża do toczenia gwintów zworników rur wiertniczych kształtu IV po długiej eksploatacji.

Rysunek 12 przedstawia schemat, który łączy kontury profilu krawędzi skrawającej nowego noża tokarskie- go z rysunku 10 (krzywa czarna ciągła) i zużytego na rysunku 11 (krzywa czerwona punktowa). Jeśli porównać te linie, stanie się jasne, że krawędź skrawająca jest najbardziej zużyta w części, która tworzy podstawę gwintu.

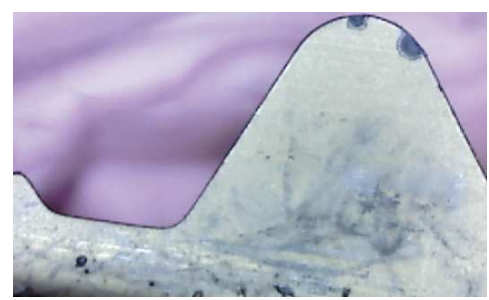

Rys. 10. Zdjęcie z części ostrza noża (wykonywane przy powiększeniu 20×)

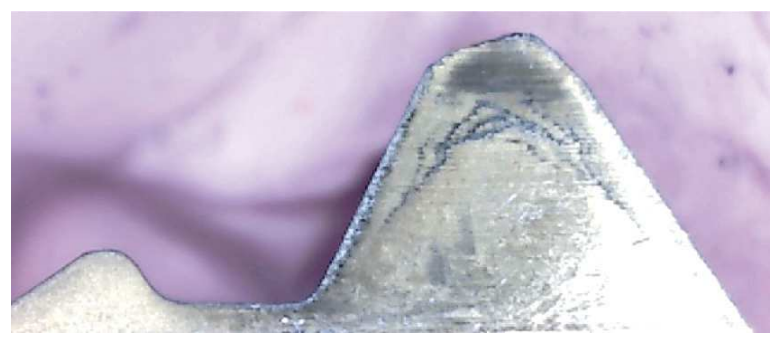

Rys. 11. Zdjęcie z części ostrza noża. Ten sam nóż jest $z$ petnym profilem krawędzi tylko po zakończeniu stosowania w obrabiarce (ksztalt IV, wykonywane przy powiększeniu 20×)

Z rysunku 12 można wywnioskować, że dalsza eksploatacja noża obniży czerwoną punktową krzywą poniżej linii zarysu wierzchołka, co spowoduje, że mufa nie złączy się z czopem w wyniku interferencji ich powierzchni gwintowej.

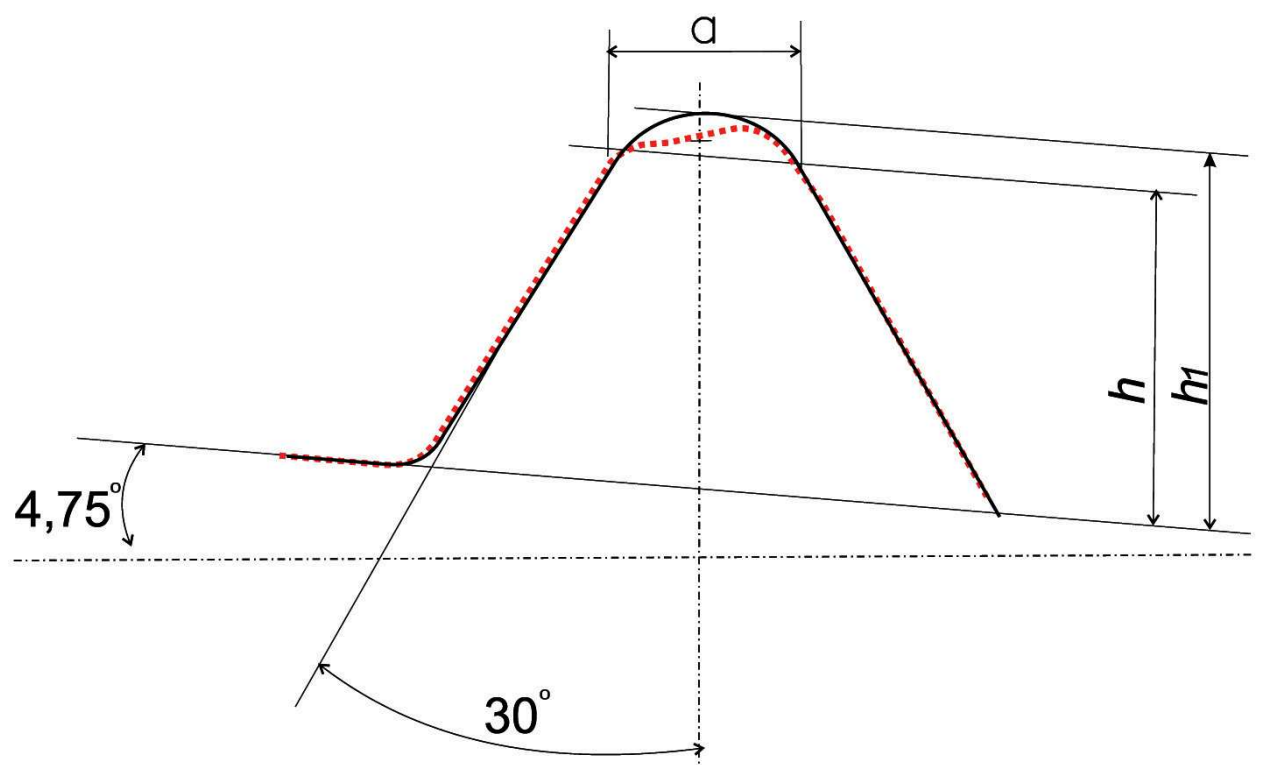

Rys. 12. Schemat połączonych konturów nowego noża do toczenia zwornikowej powierzchni gwintowej (czarna krzywa) i noża ze zużytym profilem krawędzi skrawającej (czerwona punktowa krzywa) 


\subsection{Zapewnienie zwiększenia szczelności zwornika dzięki zmniejszeniu luki technologicznej}

Aby zmniejszyć początkową wartość wysokości szczeliny, która jest określona przez wcześniej przyjęty wzór $h_{1}-h$, lepszym rozwiązaniem jest zwiększenie wartości $h$ niż zmniejszenie wartości $h_{1}$. Wynika to z faktu, że podstawę powierzchni gwintowej tworzy część krawędzi noża, która zużywa się najintensywniej, dlatego niewłaściwe jest jego zmniejszanie. Ale całkiem rozsądne jest zwiększenie wartości $h$. Oznacza to, że warto zwiększyć ten parametr w odpowiedniej sekcji krawędzi narzędzia.

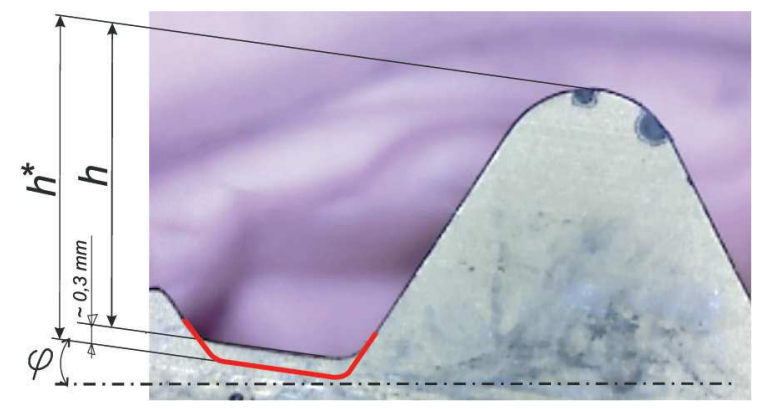

Rys. 13. Zdjęcie z części ostrza noża (wykonywane w powiększeniu $20 \times$ ), z poprawionym odcinkiem krawędzi skrawajacej, schemat fragmentu połaczenia rur wiertniczych $z$ większa o 0,3 $\mathrm{mm}$ wysokościa robocza profilu gwintu (krzywa czerwona)
Rysunek 13 pokazuje obraz krawędzi skrawania noża, który jest podobny do rysunku 10 oraz dodatkowo narzucony zmodernizowany profil (czerwona linia), który potwierdza, że wzrost wielkości $h$ do wartości $h^{*}$ był spowodowany przeniesieniem krawędzi skrawania, która tworzy wierzchołek przy cięciu gwintu o $0,3 \mathrm{~mm}$ zgodnie z zaleceniami [4].

\subsection{Zapewnienie wymaganego okresu trwałości noża do toczenia powierzchni gwintowej zworników rur wiertniczych}

Rysunek 14 przedstawia schemat pozwalający na uzyskanie zmniejszenia szczeliny technologicznej pozwalający na uzyskanie $h_{1}-h^{*}$, która może być wykonana za pomocą noża z dostosowaną krawędzią, jak pokazano na rysunku 13. Czerwona krzywa punktowa na rysunku 14 wskazuje najbardziej charakterystyczne zużycie krawędzi tnącej w momencie zakończenia okresu trwałości noża.

Jest oczywiste, że wartości $h *$ nie można zapewnić kontaktu $\mathrm{z}$ taką krawędzią, ponieważ wykracza ona poza granicę figury umieszczonej między wymiarami $h_{1}$ i $h^{*}$. W takim przypadku należy zadbać o trwałość noża, dostosowując jego parametry geometryczne, przede wszystkim statyczny kąt natarcia w wierzchołku ostrza noża - na przykład w zakresie $-5^{\circ}$ zgodnie z zaleceniami $[9,10]$.

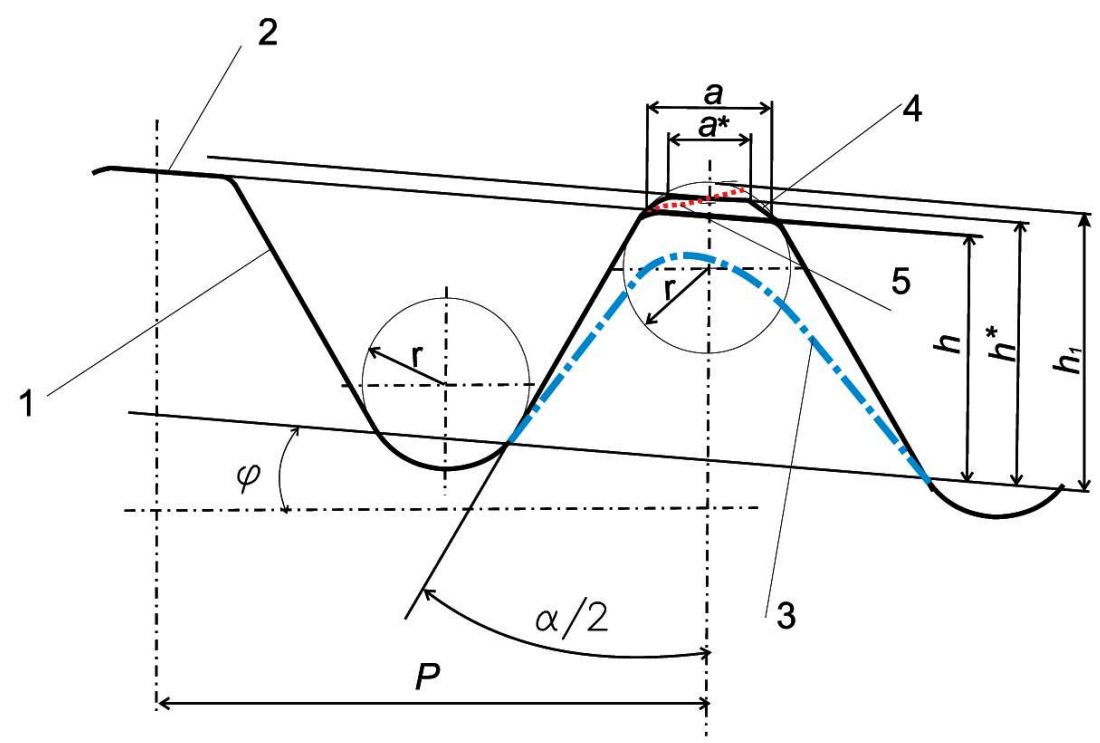

Rys. 14. Schemat ilustrujący zmniejszenie poczatkowej szczeliny i w konsekwencji zmniejszenie teoretycznego ograniczenia zużycia krawędzi skrawającej narzędzia przez zwiększenie wartości $h$ do rozmiaru $h^{*}: 1$ - większa strona profilu gwintu zgodnie ze standardem, 2 - wierzchotek profilu gwintu zgodnie ze standardem, 3 - profil gwintu po dhugiej eksploatacji, 4 - wierzchołek gwintu, który jest wykonywany za pomoca dopasowanej krawędzi skrawającej, 5 - krawędź skrawająca noża tokarskiego po dhugiej eksploatacji 


\section{ZWIĘKSZENIE WARTOŚCI KRYTERIUM ODRZUCENIA $H$ I WARTOŚCI LICZBY WKRĘCEŃ DLA PEŁNEGO WKRĘCANIA $m$}

Rysunki 13 i 14 pokazują, że wartość $h$ można zwiększyć do wielkości $h^{*}$, a zatem wartość $a$ zmniejsza się do $a^{*}$. Wzory w rozdziale 10.1 zawierają zmienne $h$ i $a$, więc należy obliczyć następujące parametry: kryteria odrzucenia i liczbę powtórzeń wkręcania w celu uzyskania wyników, które potwierdzą pogląd, że zmodernizowany według rysunku 13 nóż przy stosowaniu zaleceń $[9,10]$ zwiększy określone parametry.

\subsection{Przykład}

\section{obliczenia kryterium $\boldsymbol{H}$ i wartości $\boldsymbol{m}$ dla gwintu połączenia zwornika o kształcie profilu IV}

Skok $P=6,35 \mathrm{~mm}$, wysokość robocza profilu gwintu $h=2,633 \mathrm{~mm}$, stożek $K=0,17$.

Zgodnie ze źródłem [3, 4] spadek wartości zmiennej $a$ od wartości $1,65 \mathrm{~mm}$ do wartości $1 \mathrm{~mm}$ można osiągnąć, dodając do wartości $h$ jeszcze $0,328 \mathrm{~mm}$. Jednocześnie, zgodnie z [3], prędkość przepływu płynu wiertniczego przez szczelinę zmaleje 30-50 razy, co oznacza gwałtowny spadek działania procesu ściernego na zużycie połączenia. Podstawiamy te wartości we wzorze (7) i wykonujemy dwa obliczenia przy $h=2,633 \mathrm{~mm}$ i przy:

$$
h^{*}=2,633+0,328=2,961 \mathrm{~mm}
$$

W związku z tym przy $h=2,633 \mathrm{~mm}$ kryterium $H=30,98 \mathrm{~mm}$, a przy $h^{*}=2941 \mathrm{~mm}$ kryterium $H^{*}=$ $=34,84 \mathrm{~mm}$. W wymiarze liczbowym na przykładzie profilu IV mamy następujący względny wzrost w kryterium $H_{\%}$ :

$$
H_{\%}=\frac{H^{*}-H}{H}=\frac{34,68-30,98}{30,98} 100=11,94 \%
$$

gdzie $H^{*}$ - kryterium $H$ o nowej wartości $h=$ $=2,961 \mathrm{~mm}$.
Zatem zwiększenie wysokości roboczej profilu $h$ o 0,328 mm prowadzi do zwiększenia kryterium odrzucania gwintów połączenia wiertniczego o prawie $12 \%$.

Podstawiamy powyższe wartości we wzorze (8) i wykonujemy dwa obliczenia przy $h=2,633 \mathrm{~mm}$ i przy $h^{*}=2,633+0,328=2,961 \mathrm{~mm}$. Zatem, przy $h=$ $=2,633 \mathrm{~mm}$, wartość liczby wkręcania $m=4,88$, a przy $h^{*}=2,961 \mathrm{~mm}$ wartość liczby wkręcania $m^{*}=5,49$. Wzór (8) wskazuje więc również na funkcjonalną zależność wkręcania zworników od profilu krawędzi skrawającej noża. W wymiarze liczbowym na przykładzie profilu IV otrzymujemy następujący względny wzrost w kryterium $m_{\%}$ :

$$
m_{\%}=\frac{m^{*}-m}{m}=\frac{5,49-4,88}{4,88} 100=12,5 \%
$$

gdzie $m^{*}$ - jest wartością liczby wkręcania przy $h^{*}=$ $2,961 \mathrm{~mm}$.

Zatem zwiększenie wysokości roboczej profilu $h$ o 0,328 mm prowadzi do zwiększenia wartości liczby wkręcania połączeń gwintowych o 12,5\%.

\subsection{Porównanie obliczonych kryteriów odrzucenia $\boldsymbol{H}$ i wartości liczby obrotów przy pełnym wkręcaniu $m$ w przypadku standardowych i ulepszonych gwintów zwornikowych o kształcie profilu IV}

Na podstawie tego przykładu oraz po zastosowaniu wzorów (3) i (5) sporządzono tabelę 1, w której przedstawiono obliczenia kryterium odrzucenia zarówno dla standardowych parametrów o kształcie profilu IV $H_{\max }$ i $H_{\min }$, jak i wykonanych za pomocą narzędzia o zmodernizowanym profilu.

Poza tym opierając się na wzorach (4) i (6), sporządzono tabelę 2, w której obliczono wartość liczby obrotów do pełnego skręcenia $m_{\max }$ i $m_{\min }$ dla standardowych parametrów kształtu IV profilu i dla profilu wykonanego za pomocą narzędzia ze zmodernizowanym profilem. 
Tabela 1

Wyniki obliczania kryteriów odrzucenia dla standardowego i zaktualizowanego wykonywania (kształt profilu IV gwintu zwornika)

\begin{tabular}{|c|c|c|c|c|c|c|c|c|}
\hline \multirow{2}{*}{ Parametr } & \multicolumn{3}{|c|}{ Wartości standardowe } & \multicolumn{3}{|c|}{ Wartości zaktualizowane } & \multicolumn{2}{|c|}{ Względny wzrost } \\
\hline & $\begin{array}{c}\text { Wartość } \\
\text { parametru }\end{array}$ & $\begin{array}{c}\boldsymbol{H}_{\min } \\
{[\mathrm{mm}]}\end{array}$ & $\begin{array}{l}H_{\max } \\
{[\mathrm{mm}]}\end{array}$ & $\begin{array}{c}\text { Wartość } \\
\text { parametru }\end{array}$ & $\begin{array}{l}H^{*}{ }_{\min } \\
{[\mathrm{mm}]}\end{array}$ & $\begin{array}{l}H^{*}{ }_{\max } \\
{[\mathrm{mm}]}\end{array}$ & $\begin{array}{c}\boldsymbol{H}_{\min \%} \\
{[\%]}\end{array}$ & $\underset{[\%]}{H_{\max } \%}$ \\
\hline$P$ & 6,35 & \multirow{5}{*}{28,08} & \multirow{5}{*}{30,98} & 6,35 & \multirow{5}{*}{30,74} & \multirow{5}{*}{34,84} & \multirow{5}{*}{9,4} & \multirow{5}{*}{11,94} \\
\hline$K$ & $1: 6$ & & & $1: 6$ & & & & \\
\hline$a$ & 1,65 & & & 1 & & & & \\
\hline$h$ & 2,63 & & & 2,96 & & & & \\
\hline$a$ & 30 & & & 30 & & & & \\
\hline
\end{tabular}

Tabela 2

Wyniki obliczania wartości liczby obrotów dla standardowego i zaktualizowanego wykonywania (kształt profilu IV gwintu zwornika)

\begin{tabular}{|c|c|c|c|c|c|c|c|c|}
\hline \multirow{2}{*}{ Parametr } & \multicolumn{3}{|c|}{ Wartości standardowe } & \multicolumn{3}{|c|}{ Wartości zaktualizowane } & \multicolumn{2}{|c|}{ Względny wzrost } \\
\hline & $\begin{array}{c}\text { Wartość } \\
\text { parametru }\end{array}$ & $\begin{array}{c}m_{\min } \\
\text { [об] }\end{array}$ & $\begin{array}{c}m_{\max } \\
\text { [об] }\end{array}$ & $\begin{array}{c}\text { Wartość } \\
\text { parametru }\end{array}$ & $\begin{array}{c}m_{\min } \\
\text { [об] }\end{array}$ & $\begin{array}{c}m_{\max } \\
\text { [об] }\end{array}$ & $\begin{array}{c}m_{\min \%} \\
{[\%]}\end{array}$ & $\begin{array}{c}m_{\max \%} \\
{[\%]}\end{array}$ \\
\hline$P$ & 6,35 & \multirow{5}{*}{4,42} & \multirow{5}{*}{4,88} & 6,35 & \multirow{5}{*}{4,84} & \multirow{5}{*}{5,49} & \multirow{5}{*}{14,5} & \multirow{5}{*}{12,5} \\
\hline$K$ & $1: 6$ & & & $1: 6$ & & & & \\
\hline$a$ & 1,65 & & & 1 & & & & \\
\hline$h$ & 2,63 & & & 2,96 & & & & \\
\hline$a$ & 30 & & & 30 & & & & \\
\hline
\end{tabular}

\section{WNIOSKI}

Na podstawie stosowania kryteriów odrzucenia i badań teoretycznych profilu krawędzi skrawającej noży przeznaczonych do toczenia powierzchni gwintów zwornikowych sformułowano następujące wnioski.

1. Zwiększenie wysokości roboczej profilu $h$ i zmniejszenie szerokości wartości $a$ noża prowadzi jednocześnie do zwiększenia szczelności połączenia gwintu w zworniku i wartości kryterium odrzucenia $H$ o $9-12 \%$.

2. Zwiększenie wysokości roboczej profilu $h$ oraz zmniejszenie szerokości $a$ profilu krawędzi skrawającej prowadzi do zwiększenia wartości liczby obrotów $m$ od momentu zainstalowania czopa w mufie do ich pełnego wkręcania o 12,5-14,5\%.
3. Zwiększenie wysokości roboczej profilu $h$ i zmniejszenie szerokości wierzchołka $a$ na gwincie zwornika nie prowadzi do naruszeń standardów GOST 28487-90 i API 7, ponieważ są to wielkości opcjonalne.

\section{Literatura}

[1] HOST 28487-90. Mieżgosudarstwiennyj standart. Riez'ba koniczeskaja zamkowaja dla elemientow burilnych kołonn. Profil. Razmiery. Dopuski, „Standartinform” 2010: 75.

[2] Czudyk I.I.: Do wtrat hidrawlicznoji enerhiji pid czaspromywannia swerdlowyny, „Rozwidka ta rozrobka naftowych i hazowych rodowyszcz" 2009, 2: 34-42.

[3] Borushchak L., Onysko O., Panchuk V.: Research of the impermeability of the tool-joint tape red thread size $27 / 8$ reg, Monografia TUR „Problemy Eksploatacji i Zarządzania w Górnictwie”, Kraków 2017: 65-72. 
[4] Borushchak L., Borushchak S., Onysko O.: Influence of the technological gap value of the tool-joint tapered thread on the drilling mud flow rate in its screw coupling, „Ukrainian Journal of Mechanical Engineering and Materials Science" 2017, 3, 2: 24-31.

[5] Thread_turning/thread_turning_brochure_english.pdf. www. secotools.com/CorpWēb/Products/Turning/ [dostęp 2017].

[6] Siemin W.I.: Sowriemiennyje mietody projektirowanija riez'bowych sojedinienij trub nieftiegazowogo sortamienta dla stroitielstwa skważyn: awtoriefierat dis. doktora tiechniczeskich nauk, Moskwa 2005.

[7] Onysko O.: Pro funkcionalnu załeżnist' wetyczyny połowynnohokuta profilu zamkowoji narizi wid wetyczyn peredn'ioho kuta, kuta nachytu ta połowynnoho kuta profilurizalnoji kromky rizcia, w: Optymizacija wyrobnyczych procesiw $i$ technicznyj kontrol u maszynobuduwanni ta pryładobuduwanni, „Wisnyk Nacionalnoho uniwersytetu «Lwiws'ka politechnika»" 2017, 867: 10-28.

[8] Onysko O.: Athorytm rozrachunku funkcionalnoji załeżnosti formy bicznych profiliwhwyntowoji narizi zamkowoji konicznoji dla etementiw burylnych koton wid heometrycznych parametriwrizcia, „Naukowij wisnyk” 2017, 1: 77-81.
[9] Onyśko O.R., Psiuk M.I.: Analiz zabezpeczennia tocznostiprofilu zamkowoji narizi wyhotowtenoji rizciamy iz zahalnym położenniam peredńioji powerchni ta zadanoji tocznistiu jiji wstanowtennia, „Wisnyk NTU «CHPI». Serija: Technołohija w maszynobuduwanni" 2017, 17: 10-17.

[10] Onysko O., Panchuk V., Medvid J.: Technology of the oil and gas drill string pipe connector manufacturing with lowpermeability level of the drilling mud in it's screw part, $6^{\text {th }}$ International Conference of Applied Science, Banja Luka 2018.

dr hab. inż. VITALII PANCHUK

drinż. OLEH ONYSKO.

mgr inż. TETIANA LUKAN

mgr inż. IULIIA MEDVID

Iwano-Frankiwski Narodowy Techniczny Uniwersytet

Nafty $i$ Gazu

ul. Karpatska15, Iwano-Frankiwsk, Ukraina

kmv@nung.edu.ua 